\title{
FEMA GRAS assessment of natural flavor complexes: Origanum oil, thyme oil and related phenol derivative-containing flavoring ingredients
}

\author{
Samuel M. Cohen ${ }^{\mathrm{a}}$, Gerhard Eisenbrand ${ }^{\mathrm{b}}$, Shoji Fukushima ${ }^{\mathrm{c}}$, Nigel J. Gooderham ${ }^{\mathrm{d}}$, F. \\ Peter Guengerich $^{\mathrm{e}}$, Stephen S. Hecht ${ }^{\mathrm{f}}$, Ivonne M.C.M. Rietjens ${ }^{g}$, Thomas J. Rosol ${ }^{\mathrm{h}}$, Jeanne \\ M. Davidsen ${ }^{i}$, Christie L. Harman ${ }^{i}$, Vivian Lu ${ }^{i}$, Sean V. Taylor ${ }^{j}$," \\ ${ }^{a}$ Dept. of Pathology and Microbiology, University of Nebraska Medical Center, 983135 Nebraska Medical Center, Omaha, NE, 68198-3135, USA \\ ${ }^{\mathrm{b}}$ University of Kaiserslautern, Germany (Retired), Kühler Grund 48/1, 69126, Heidelberg, Germany \\ ' Japan Bioassay Research Center, 2445 Hirasawa, Hadano, Kanagawa, 257-0015, Japan \\ ${ }^{\mathrm{d}}$ Dept. of Metabolism, Digestion, Reproduction, Imperial College London, Sir Alexander Fleming Building, London, SW7 2AZ, United Kingdom \\ e Dept. of Biochemistry, Vanderbilt University School of Medicine, Nashville, TN, 37232-0146, USA \\ ${ }^{\mathrm{f}}$ Masonic Cancer Center and Dept. of Laboratory Medicine and Pathology, Cancer and Cardiovascular Research Building, 2231 6th St. S.E., Minneapolis, MN, 55455, \\ USA \\ ${ }^{\mathrm{g}}$ Division of Toxicology, Wageningen University, Stippeneng 4, 6708, WE, Wageningen, the Netherlands \\ ${ }^{\mathrm{h}}$ Department of Biomedical Sciences, Heritage College of Osteopathic Medicine, Ohio University, 1 Ohio University, Athens, OH, 45701, USA \\ ${ }^{i}$ Flavor and Extract Manufacturers Association, 1101 17th Street NW, Suite 700, Washington, DC, 20036, USA \\ ${ }^{\mathrm{j}}$ Scientific Secretary to the FEMA Expert Panel, 1101 17th Street, N.W., Suite 700, Washington, D.C., 20036, USA
}

\section{A R T I C L E I N F O}

Handling Editor: Dr. Jose Luis Domingo Natural flavor complexes

Essential oils

Phenols - simple

Safety evaluation

GRAS

\begin{abstract}
A B S T R A C T
In 2015, the Expert Panel of the Flavor and Extract Manufacturers Association (FEMA) initiated a re-evaluation of the safety of over 250 natural flavor complexes (NFCs) used as flavor ingredients, mostly consisting of a variety of essential oils and botanical extracts. This publication, seventh in the series, re-evaluates NFCs with constituent profiles dominated by phenolic derivatives including carvacrol, thymol and related compounds using a constituent-based procedure first published in 2005 and updated in 2018. The procedure is based on the chemical characterization of each NFC as intended for commerce and the estimated intake of the constituent congeneric groups. The procedure applies the threshold of toxicological concern (TTC) concept and evaluates relevant data on absorption, metabolism, genotoxic potential and toxicology of the constituent congeneric groups and the NFC under evaluation. Herein, the FEMA Expert Panel affirmed the generally recognized as safe (GRAS) status of seven phenolic derivative-based NFCs, Origanum Oil (Extractive) (FEMA 2828), Savory Summer Oil (FEMA 3013), Savory Summer Oleoresin (FEMA 3014), Savory Winter Oil (FEMA 3016), Savory Winter Oleoresin (FEMA 3017), Thyme Oil (FEMA 3064) and Thyme White Oil (FEMA 3065) under their conditions of intended use as flavor ingredients.
\end{abstract}

\section{Introduction}

Since 1960, the Expert Panel of the Flavor and Extract Manufacturers Association (FEMA) has operated as the primary independent evaluation body of flavoring ingredients for use in foods and beverages in the United States. Flavoring ingredients are evaluated to establish their "generally recognized as safe" (GRAS) status under the conditions of their intended use in a manner consistent with the 1958 Food Additive Amendment to the Federal Food Drug and Cosmetic Act (Hallagan and Hall, 1995, 2009; Hallagan et al., 2020). In the past six decades, the
FEMA Expert Panel has evaluated over 2700 flavoring ingredients, for which it has assigned GRAS status for their intended uses.

As part of FEMA's GRAS program, the Expert Panel continues to reevaluate and affirm the GRAS status of flavoring ingredients, which include chemically defined substances and natural flavor complexes (NFCs). Re-evaluations for chemically-defined flavoring ingredients began in the 1990's and were expanded to include NFCs in 2015. The scientifically-based procedure used to conduct safety evaluations on NFCs was first published in Smith et al. (2005) and was updated in 2018 (Cohen et al., 2018). As part of the evaluation procedure, NFCs are assessed based on a constituent-guided approach. The constituents that

\footnotetext{
* Corresponding author.

E-mail address: staylor@vertosolutions.net (S.V. Taylor).
} 


$\begin{array}{ll}\text { Abbreviations } \\ \text { CA } & \text { Chromosomal aberration } \\ \text { CBPI } & \text { Cytokinesis-block proliferation index } \\ \text { CF } & \text { Correction factor } \\ \text { CG } & \text { Congeneric group } \\ \text { DTC } & \text { Decision tree class } \\ \text { EC } 50 & \text { Concentration resulting in a 50\% change versus controls } \\ \text { EFFA } & \text { European Flavour Association } \\ \text { EFSA } & \text { European Food Safety Authority } \\ \text { FCC } & \text { Food Chemicals Codex } \\ \text { ERS/USDA Economic Research Service/United States Department } \\ \\ \text { FDA } & \text { of Agriculture } \\ \text { FEMA } & \text { Food and Drug Administration and Extract Manufacturers Association } \\ \text { FID } & \text { Flame ionization detector } \\ \text { FPG } & \text { Formamidopyrimidine glycosylase } \\ \text { GC-MS } & \text { Gas chromatography-mass spectrometry } \\ \text { GLP } & \text { Good laboratory practices } \\ \text { GMP } & \text { Good manufacturing practices } \\ \text { GRAS } & \text { Generally recognized as safe } \\ \text { HPBL } & \text { Human peripheral blood lymphocytes }\end{array}$

IFEAT International Federation of Essential Oils and Aroma Trades

IOFI International Organization of the Flavor Industry

JECFA Joint FAO/WHO Expert Committee on Food Additives

JFFMA Japan Fragrance and Flavor Materials Association

MoS Margin of safety

NFC Natural flavoring complex

MTS 3-(4,5-Dimethylthiazol-2-yl)-5-(3carboxymethoxyphenyl)-2-(4-sulfophenyl)-2Htetrazolium salt (reduction assay)

NOAEL No observed adverse effect level

NR Neutral red cellular uptake (assay)

OECD Organization for Economic Co-Operation and Development

PC Protein content

PCI Per capita intake

SCE Sister chromatid exchange (assay)

SHE Syrian hamster embryo (cells)

TTC Threshold of toxicological concern

UDS Unscheduled DNA synthesis (assay)

WHO World Health Organization. comprise these NFCs are usually derived from well-studied biochemical pathways such as the isoprene, shikimate, lipoxygenase oxidation and photosynthetic pathways, and therefore can be organized into a defined number of well-established chemical groups, referred to as congeneric groups. Information compiled relating to the estimated intake, metabolism and toxicology of these NFCs and their constituent congeneric groups are systematically reviewed in the safety evaluation procedure. The Expert Panel has applied this procedure to the safety evaluation of Citrus-derived NFCs (Cohen et al., 2019), Mentha, dill, buchu and caraway-derived NFCs (Cohen et al., 2020), Cassia, Cinnamomum and Myroxylon-derived NFCs (Rietjens et al., 2020), clove, cinnamon leaf and West Indian bay leave-derived NFCs (Gooderham et al., 2020a), lavender, guaiac, coriander-derived and related NFCs (Fukushima et al., 2020) and Eucalyptus-derived and other eucalyptol containing NFCs (Eisenbrand et al., 2021).

The FEMA Expert Panel issued a call for data in 2018 requesting compositional data information for the NFCs listed in Table 1, which include NFCs derived from the Thymus and Satureja genera currently used for flavoring foods and beverages. As part of the industry-wide call for data, members of FEMA, the International Organization of the Flavor Industry (IOFI), the European Flavour Association (EFFA) and the Japan Fragrance and Flavor Materials Association (JFFMA), along with the International Federation of Essential Oils and Aroma Trades (IFEAT) provided the data on these seven NFCs to assist in their safety evaluations.

\section{History of food use}

For centuries, the plants from the Thymus genus have been used for flavoring foods and as traditional medicine. The Romans used it to ward off venomous creatures and to flavor cheeses and liqueurs (Charles, 2013; Grieve, 1970). Its name stems from the Greek language in which it can mean "courage or strength," with early Greeks associating the herb with elegance (Charles, 2013). Its perceived antiseptic properties led to its use during the Black Plague, as well as during World War I (Charles, 2013). The cultivation of thyme was spread into central Europe and England in the Middle Ages by Benedictine monks, who incorporated it into their famous "elixir" liqueur (Charles, 2013). Both dried and fresh thyme leaves are available in Western food markets and are added to popular Mediterranean sauces and spice blends such as za'atar, Herbes de Provence and bouquet garni. (Charles, 2013; Lawrence and Tucker, 2002). Origanum Oil (FEMA 2828), although derived from a member of the Thymus genus, Thymus capitatus L. Hoffm. Et Link, is also known as Spanish oregano oil due to its similar appearance to Origanum vulgare. Thymus vulgaris L. and T. capitatus Hoffm. Et Link are often cultivated in kitchen gardens for use in food (Lawrence and Tucker, 2002).

Table 1

NFCs evaluated by the Expert Panel.

\begin{tabular}{|c|c|c|c|}
\hline Name & FEMA No. & $\begin{array}{c}\text { Estimated } \\
\text { Intake }(\mu \mathrm{g} / \text { person } / \text { day })^{1}\end{array}$ & Most Recent Annual Volume $(\mathrm{kg})^{2}$ \\
\hline Origanum Oil (Extractive) [Thymus capitatus Hoffm. Et Link (syn. Coridothymus capitatus Reich b.)] & 2828 & 630 & 6070 \\
\hline Savory Summer Oil (Satureja hortensis L.) & 3013 & 0.05 & 0.5 \\
\hline Savory Summer Oleoresin (Satureja hortensis L.) & 3014 & 0.04 & $0.4^{3}$ \\
\hline Savory Winter Oil (Satureja montana L.) & 3016 & 0.7 & 7 \\
\hline Savory Winter Oleoresin (Satureja montana L.) & 3017 & 1 & $11^{4}$ \\
\hline Thyme Oil (Thymus vulgaris L., T. zygis) & 3064 & 220 & 2130 \\
\hline Thyme White Oil (Thymus vulgaris L., T. zygis) & 3065 & 3 & 25 \\
\hline
\end{tabular}

${ }^{1}$ For all NFCs, PCI $\times 10$ ("eaters only') method used to calculate estimated intake.

${ }^{2}$ Harman, C.L. and Murray, I.J, 2018. 2015 Poundage and Technical Effects Survey. Flavor and Extract Manufacturers Association, Washington, DC, USA.

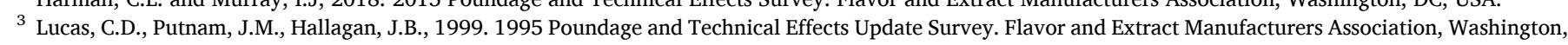
DC, USA.

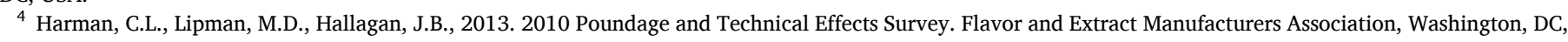
USA. 
The poet Virgil recommended that savory be grown near beehives to yield a fragrant honey (Charles, 2013; Grieve, 1970). Savory summer and savory winter belong to the genus Satureja, the name of which is derived from the word "satyr." These mythical half-man, half-goat creatures were considered the keepers of the savory plant by the Greeks and Romans (Charles, 2013). The Romans also shared the savory summer plant with the English, who then mixed the herb with bread crumbs to use it as a coating for meats in the seventeenth century (Charles, 2013). Both species of savory are cultivated and used in a similar culinary fashion to thyme. Although remarkably similar to each other, the annual summer savory possesses a slightly less bitter taste than the perennial winter savory. Savory is an ingredient in the popular Herbs de Provence blend often used in meat and soup recipes.

In the twentieth century, the use of spice oleoresins became increasingly prevalent in processed foods. Spice oleoresins, prepared by the extraction of a spice or herb such as summer savory and winter savory, contain both the essential oil and resinous fractions of the spice or herb and are highly concentrated flavor ingredients compared to the botanicals from which they are derived. Spice/herb oleoresins used as flavoring ingredients are often standardized to contain a specific percentage of essential oil by dilution with food grade ingredients. Because oleoresins can be concentrated, standardized and more easily stored and handled, they have found use in some processed foods in place of whole or ground spices and herbs.

\section{Current usage}

The NFCs presented in Table 1 are used in a diverse array of commercial products including baked goods, chewing gum, condiments and relishes, confections and frostings, frozen dairy, gelatins and puddings, gravies, hard candy, meat products, soft candy, soups and various beverages. The most recent annual poundage (Harman et al., 2013, 2018; Lucas et al., 1999), and the estimated intake of each NFC are presented in Table 1. Of the NFCs under consideration, Origanum Oil (Extractive) (FEMA 2828) had both the highest annual usage and estimated intake of $630 \mu \mathrm{g} /$ person/day. Of the other NFCs, only Thyme Oil (FEMA 3064) has an estimated per capita consumption greater than $3 \mu \mathrm{g} /$ person/day.

Although the herbs from the Thymus and Satureja genera are commonly grown in household gardens and can be found fresh or dried in markets across the globe, usage data as consumed food are not available for the calculation of per capita consumption.

\section{Manufacturing methodology}

Hardy herbs of the Thymus and related Satureja genera are native to southern and central Europe, with Spain being a major cultivator and producer of many of their essential oils and extractives (Charles, 2013; Lawrence, 2014). Thyme oil, also referred to as red thyme oil, is obtained from the steam distillation of the whole above-ground flowering plant of T. vulgaris L. or T. zygis, which is harvested at the beginning of full bloom when the plant is at its most aromatic stage (Arctander, 1961; Venskutonis, 2002). The characteristic red color of the oil, which differentiates it from white thyme oil, is attributed to the interaction between one of its constituents, thymol, and the iron in the field stills (Lawrence and Tucker, 2002). Thyme white oil, characterized by a higher thymol content, is obtained from thyme (red) oil by rectification, or further distillation, which removes the color and other semi-volatile constituents (Lawrence and Tucker, 2002; Venskutonis, 2002). Two species of savory, Satureja hortensis L. and S. montana L., are grown to produce savory summer oil and savory winter oil, respectively. Savory summer oil can be referred to as garden savory oil while savory winter oil is called mountain savory oil, but both are obtained by the steam distillation of the whole flowering plant (Surburg and Panten, 2006). Colloquially called Spanish oregano or conehead thyme, Thymus capitatus Hoffm. Et Link is the source of origanum oil obtained by steam distillation of the flowering tops (Lawrence and Tucker, 2002; Surburg and Panten, 2006).

Spice/herb oleoresins such as savory summer and savory winter oleoresin are prepared by the extraction of the herb with a volatile solvent such as acetone, isopropanol, methanol, hexane or a chlorinated hydrocarbon followed by removal of the solvent from the extract by distillation. Alternatively, following the collection of the volatile oil of the herb by distillation, the non-volatile herb fraction is extracted with an approved solvent, concentrated by solvent removal then combined with the volatile portion collected earlier in the process. Acceptable solvents for the manufacture of spice/herb oleoresins and allowable levels of residual solvents in the finished oleoresin vary across different countries. In the USA, permissible solvents and allowable levels of residual solvents are listed in 21 C.F.R. $\S$ Sec. 173 subpart C and in the Food Chemical Codex (FCC) monograph on spice oleoresins (Food Chemical Codex, 2020). In addition, the FCC standard on spice/herb oleoresins requires that the essential oil of an oleoresin be similar in its physical and chemical properties, including its infrared spectrum, as that distilled from the spice of the same origin.

\section{Chemical composition}

The NFCs listed in Table 1 are characterized by their volatile constituents. These constituents are typically analyzed by gas chromatography-mass spectrometry (GC-MS) to identify constituents against a standardized library. GC with a flame ionization detector (FID) is typically utilized for quantitation of each recorded chromatographic peak. Recorded GC peaks, either identified or not, are reported as the area percent of their respective chromatogram. The constituent data for each NFC were compiled into summaries presented in Appendix A. Constituents with a confirmed identity were assigned both a Cramer decision tree class and a congeneric group (Cohen et al., 2018; Cramer et al., 1978). Both assignments are based on the constituent structures (Cohen et al., 2018; Cramer et al., 1978). The congeneric groups presented in Cohen et al. (2018) are consistent with the chemical groups utilized by the Joint FAO/WHO Expert Committee on Food Additives (JECFA) in its evaluation of chemically defined flavor materials.

The structures and congeneric groups of thymol, carvacrol, $p$-mentha-1,4-diene and $p$-cymene, commonly identified constituents among the listed NFCs, are shown in Fig. 1. Constituent congeneric group profiles for each NFC are shown in Fig. 2. Group 20 (Phenol derivatives) constituents, such as thymol and carvacrol, were present among all listed NFCs. The portion of total NFC composition from the combination of these two constituents ranged from $71 \%$ in Origanum Oil (Extractive) (FEMA 2828) to $47 \%$ in Thyme Oil (FEMA 3064). The second most dominant congeneric group was Group 19 (Aliphatic and aromatic hydrocarbons) constituents. The most prevalent compounds from Group 19 were $p$-cymene and $p$-mentha-1,4-diene, which have been identified as precursors in the biosynthesis of carvacrol and thymol (Stahl-Biskup, 2002). Finally, Group 12 (Aliphatic and aromatic tertiary alcohols and related esters) constituents were also present in all NFCs.

Because of the variable nature of the constituent profile of spice oleoresins, they are characterized separately from the essential oil NFCs. Raw spice oleoresins are highly concentrated and consequently, they are often standardized using a food grade ingredient that also provides an associated solubility profile for the standardized oleoresin. For example, for oil-based applications, an oleoresin may be standardized with an edible vegetable oil. Alternatively, a raw oleoresin may be standardized with a polysorbate ester that results in a water-soluble standardized oleoresin. Oleoresins may be spray-dried with a modified starch or dispersed on a food grade carrier such as salt or dextrose (Reineccius, 1994). For example, although a raw savory oleoresin may contain approximately $20 \%$ essential oil with $80 \%$ resinous material, after standardization with a food-grade diluent, it will contain a much lower percentage of essential oil and resin, as depicted in Fig. 3. While a spice oleoresin is always composed of essential oil, resinous material and the standardization agent, the customization of spice oleoresins for specific 


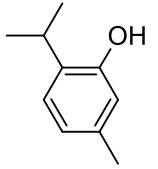

Thymol Group 20

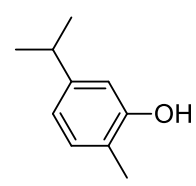

Carvacrol
Group 20

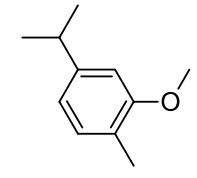

Carvacrol methyl ether Group 20

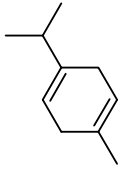

p-Mentha-1,4-diene (gamma-Terpinene) Group 19

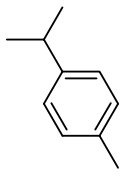

p-Cymene Group 19

Fig. 1. Structures and congeneric group of commonly reported constituents in NFCs under consideration.

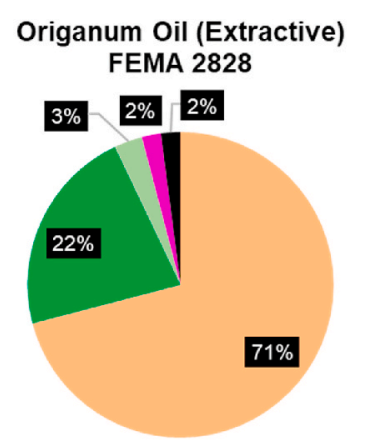

Savory Summer Oil FEMA 3013

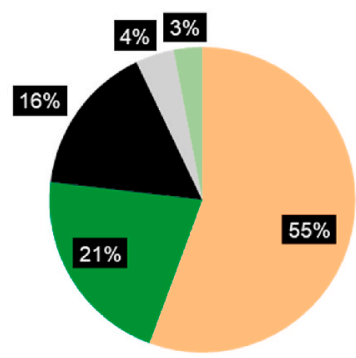

Savory Winter Oil FEMA 3016

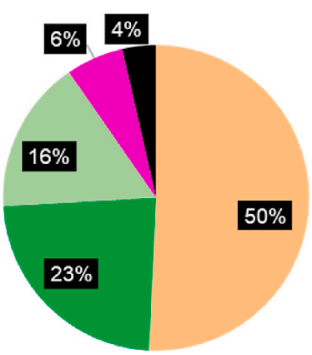

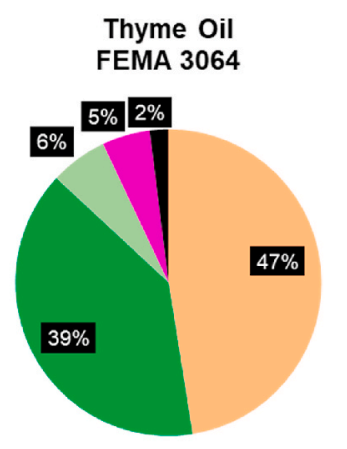

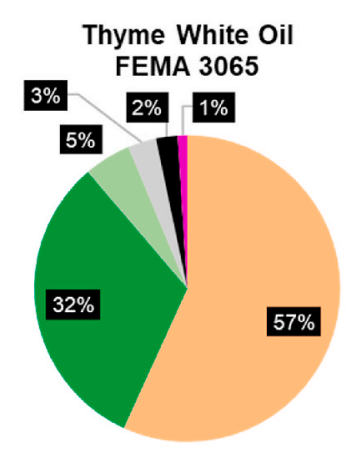

Group 20 - Phenol derivatives

Group 19 - Aliphatic and aromatic hydrocarbons

Group 12 - Aliphatic and aromatic tertiary alcohols and related esters

Group 10 - Alicyclic ketones, secondary alcohols and related esters

Unidentified Constituents

Sum of Minor Constituents

Fig. 2. Constituent congeneric group profiles for the NFCs under consideration.

applications does not allow the determination of a single chemical composition. Nevertheless, since the added constituents are food grade, the safety evaluation can be based on the estimated percentage of essential oil, 5-20\% and non-volatile components in Savory Summer Oleoresin (FEMA 3014) and Savory Winter Oleoresin (FEMA 3017).

\section{Safety evaluation}

The procedure for the safety evaluation of NFCs was guided by a set of criteria that were initially outlined in two publications (Smith et al., 2004, 2005) and updated in 2018 (Cohen et al., 2018). Briefly, as shown in Fig. 4, the NFC passes through a 14-step process; Step 1 requires the gathering of data and assesses the consumption of the NFC as a flavor relative to intake from the natural source when consumed as food; Steps 2 through 6 evaluate the exposure and potential toxicity of the identified constituents (organized by congeneric group) based on available data on metabolism and toxicity and on the application of the Threshold of Toxicological Concern (TTC) approach (Kroes et al., 2000). Steps 7-12 address the potential toxicity, including genotoxicity, of the unidentified constituents; in Step 13 the overall safety is evaluated along with considerations of safety for use by children, given their lower body weights; lastly in Step 14, the final determination of GRAS status is made. The safety evaluation is presented below in which each step of the procedure (Cohen et al., 2018) (provided in italics), is considered and answered for the NFCs under consideration. 


\section{Savory Summer Oleoresin Unstandardized}
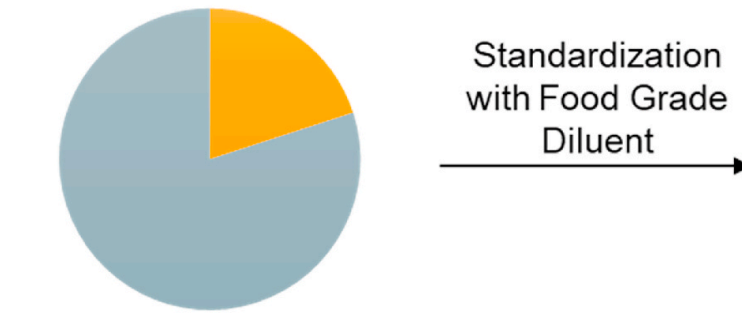

$\sim 20 \%$ Essential Oil (EO)

- $\sim 80 \%$ Non-volatile Resin

\section{Savory Summer Oleoresin \\ Standardized to $10 \%$ EO}

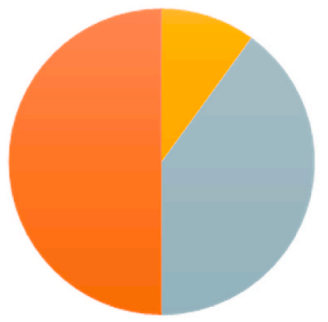

10\% Essential Oil (EO)

- 40\% Non-volatile Resin

- 50\% Standardization Agent

Fig. 3. Standardization of raw spice oleoresins, using savory summer oleoresin as an example. Savory (raw) oleoresin is standardized by dilution with a food grade standardization agent, such as vegetable oil or salt, resulting in a Savory Summer Oleoresin (FEMA 3014) composed of 10\% essential oil, approximately 50\% standardization agent and $40 \%$ non-volatile resins.

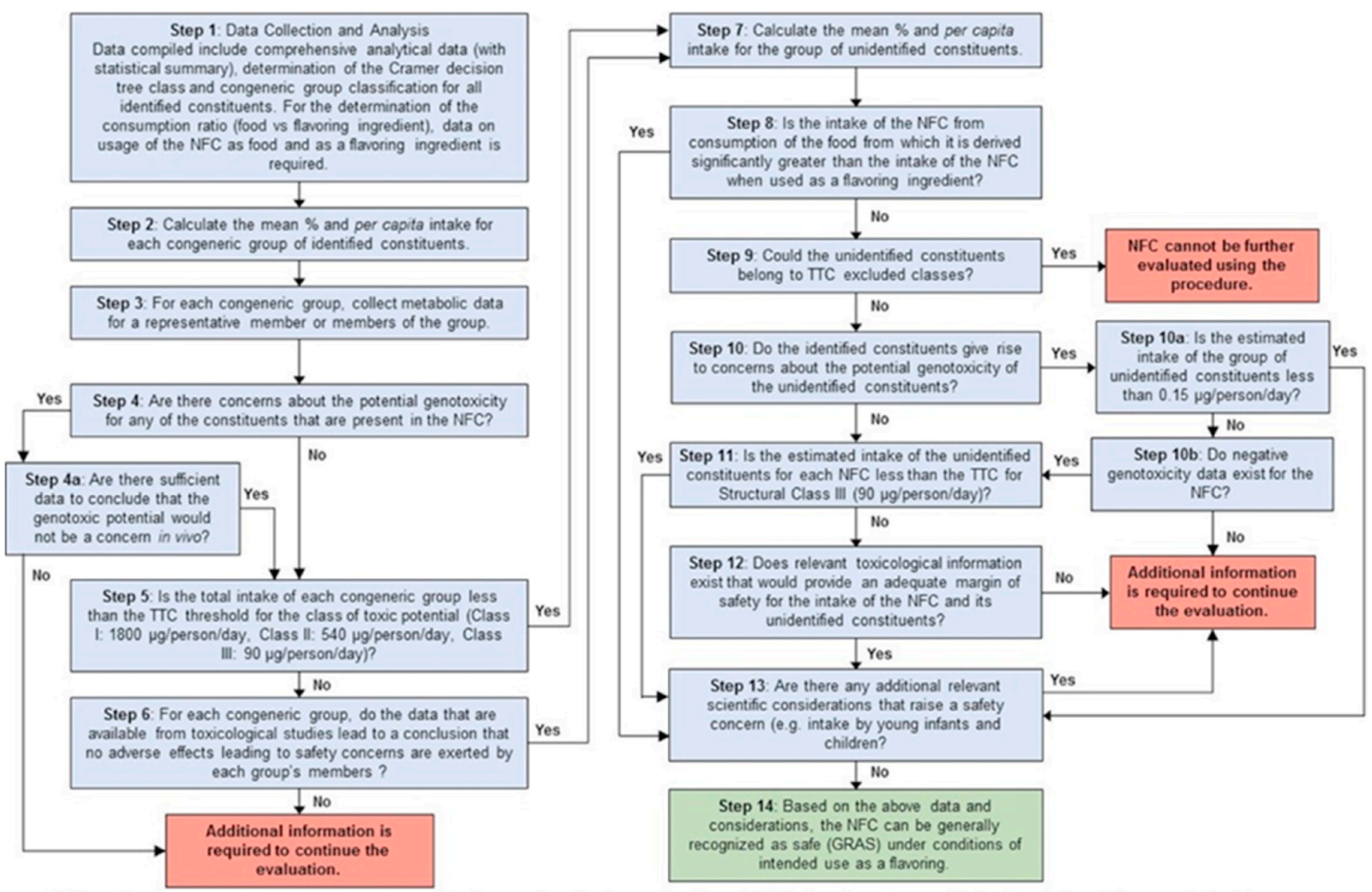

This scheme presents a summary of the revised procedure for the evaluation of NFCs to give an overall structural view. When applying the procedure, the full procedure described in the manuscript should be followed.

Fig. 4. Procedure for the safety evaluation of NFCs (Cohen et al. (2018)).

Step 1

To conduct a safety evaluation of an NFC, the Panel requires that comprehensive analytical data are provided. The analytical methodologies employed should reflect the expected composition of the NFC and provide data that identify, to the greatest extent possible, the constituents of the NFC and the levels (\%) at which they are present. It is anticipated that GC-MS and LC-MS would be used for characterization of most NFCs, and that the chromatographic peaks based on peak area of total ion current will be almost completely identified. The percentage of unknowns should be low enough to not raise a safety concern. Other appropriate methods (e.g., Karl Fischer titration, amino acid analysis, etc.) should be employed as necessary. The analytical parameters should be submitted for each type of analysis, including the method of quantitation for both identified and unidentified constituents and libraries, databases and methodology employed for the identification of analytes. The Panel requires data from multiple batches to understand the inherent variability of the NFC. 
a. consumption of foods from which the NFCs are derived

Calculate the per capita daily intake (PCI) of the NFC based on the annual volume added to food.

For NFCs with a reported volume of use greater than $22,700 \mathrm{~kg}(50,000$ lbs), the intake may be calculated by assuming that consumption of the NFC is spread among the entire population, on a case-by-case basis. In these cases, the PCI is calculated as follows:

$P C I(\mu \mathrm{g} /$ person $/$ day $)=\frac{\text { annual volume in } \mathrm{kg} \times 10^{9}}{\text { population } \times C F \times 365 \text { days }}$

where:

The annual volume of use of NFCs currently used as flavorings for food is reported in flavor industry surveys (Gavin et al., 2008; Harman et al., 2013, 2018; Lucas et al., 1999). A correction factor (CF) is used in the calculation to correct for possible incompleteness of the annual volume survey. For flavorings, including NFCs, that are undergoing GRAS re-evaluation, the $C F$, currently 0.8 , is established based on the response rate from the most recently reported flavor industry volume-of-use surveys.

For new flavorings undergoing an initial GRAS evaluation, the anticipated volume is used and a correction factor of 0.6 is applied, which is a conservative assumption that only $60 \%$ of the total anticipated volume is reported.

For NFCs with a reported volume of use less than $22,700 \mathrm{~kg}(50,000$ lbs), the eaters' population intake assumes that consumption of the NFC is distributed among only $10 \%$ of the entire population. In these cases, the per capita intake for assuming a $10 \%$ "eaters only" population $(P C I \times 10)$ is calculated as follows:

$P C I \times 10(\mu \mathrm{g} /$ person $/$ day $)=\frac{\text { annual volume in } \mathrm{kg} \times 10^{9}}{\text { population } \times C F \times 365 \text { days }} \times 10$

If applicable, estimate the intake resulting from consumption of the commonly consumed food from which the NFC is derived. The aspect of food use is particularly important. It determines whether intake of the NFC occurs predominantly from the food of which it is derived, or from the NFC itself when it is added as a flavoring ingredient (Stofberg and Grundschober, 1987) ${ }^{1}$. At this step, if the conditions of use $e^{2}$ for the NFC result in levels that differ from intake of the same constituents in the food source, it should be reported.

Thyme Oil (FEMA 3064), Thyme White Oil (FEMA 3065), Savory Summer Oil (FEMA 3013), Savory Summer Oleoresin (FEMA 3014), Savory Winter Oil (FEMA 3016), Savory Winter Oleoresin (FEMA 3017) and Origanum Oil (FEMA 2828) are all derived from popular culinary herbs. In particular, thyme is available in both fresh and dried forms in Western food markets and is often grown in home gardens (Lawrence and Tucker, 2002). Some of the botanicals from which the NFCs under consideration are derived have historically been used as spices. Although the Economic Research Service of the United States Department of Agriculture (ERS/USDA) collects import data on these herbs, these data are aggregated in its report under "other spices"(ERS/USDA, 2020). As a result, despite widespread use of these culinary herbs, reliable data on the consumption of these foods in the marketplace are not available so it is not possible to calculate a ratio for the consumption of the essential oil from food versus consumption of the essential oil as flavoring.

b. Identification of all known constituents and assignment of Cramer Decision Tree Class

In this step, the results of the complete chemical analyses for each NFC are

\footnotetext{
${ }^{1}$ See Stofberg and Grundschober (1987) for data on the consumption of NFCs from commonly consumed foods.

2 The focus throughout this evaluation sequence is on the intake of the constituents of the NFC. To the extent that processing conditions, for example, alter the intake of constituents, those conditions of use need to be noted, and their consequences evaluated in arriving at the safety judgments that are the purpose of this procedure.
}

examined, and where appropriate for each constituent the Cramer Decision Tree Class (DTC) is determined (Cramer et al., 1978).

The constituents of the NFCs under evaluation were all sorted by congeneric group, a summary of which is provided in Appendix A. Congeneric groups are ordered from highest to lowest mean \%, with only mean $\%$ greater than or equal to $1 \%$ of the total NFC reported. Constituent percentages $(<1 \%$ of the total NFC) are grouped together under each congeneric group. The total mean $\%$ of each listed congeneric group is reported.

Because chromatographic analyses for constituent composition are not available for the spice oleoresins, their constituent profiles have been derived from the information available on the volatile oil content and standardization procedures used for each oleoresin. For Savory Summer Oleoresin (FEMA 3014) and Savory Winter Oleoresin (FEMA 3017), a constituent table and summary report were prepared from data collected on the volatile oil and non-volatile composition oleoresins in commerce. Constituents are listed and a range of the values for the mean percentage and estimated intake are provided, reflecting the range of products in commerce.

\section{c. Assignment of the constituents to congeneric groups; assignment of congeneric group DTC}

In this step, the identified constituents are sorted by their structural features into congeneric groups. Each congeneric group should be expected, based on established data, to exhibit consistently similar rates and pathways of absorption, distribution, metabolism and excretion, and common toxicological endpoints (e.g. benzyl acetate, benzaldehyde, and benzoic acid are expected to have similar toxicological properties). Appendix A

For each NFC, the identified constituents and constituent congeneric groups comprising greater than $1 \%$ of the NFC and their respective DTC are reported in Appendix A.

Assign a decision tree structural class to each congeneric group. Within a congeneric group, when there are multiple decision tree structural classes for individual constituents, the class of highest toxicological concern is assigned to the group. In cases where constituents do not belong to a congeneric group, potential safety concerns would be addressed in Step 13.

Proceed to Step 2.

\section{Step 2}

Determine (a) the mean percentage (\%) of each congeneric group in $N F C s$, and (b) the daily per capita intake ${ }^{3}$ of each congeneric group. (a) Is calculated by summing the mean percentage of each of the constituents within a congeneric group, and (b) is calculated from consumption of the NFC and the mean percentage.

Calculation of PCI for each constituent congeneric group of the NFC:

Intake of congeneric group

$(\mu \mathrm{g} /$ person/day)

Mean\% congeneric group $\times$ Intake of NFC $(\mu \mathrm{g} /$ person/day $)$ 100

where:

The mean $\%$ is the mean percentage \% of the congeneric group.

The intake of NFC ( $\mu \mathrm{g} /$ person/day) is calculated using the PCI $\times 10$ or PCI equation as appropriate.

Proceed to Step 3.

Appendix A provides the summary report for each NFC, including the subtotal mean $\%$ for each congeneric group and the respective estimated intake values calculated using the PCI x 10 (eaters only) method.

\footnotetext{
${ }^{3}$ See Smith et al. (2005) for a discussion on the use of PCI $\times 10$ for exposure calculations in the procedure.
} 
Step 3

For each congeneric group, collect metabolic data for a representative member or members of the group. Step 3 is critical in assessing whether the metabolism of the members of each congeneric group would require additional considerations in Step 13 of the procedure.

Proceed to Step 4.

The constituent congeneric groups for each NFC are presented in Appendix A. Sufficient metabolic data exist for each congeneric group or related compounds that indicate constituents of these groups are expected to be metabolized to innocuous products. The use of metabolic data in the safety evaluation of flavoring compounds and a summary of the expected metabolism of flavoring compounds by congeneric group is described in a FEMA Expert Panel publication (Smith et al., 2018). In addition, the Panel has also published evaluations of metabolic data for Group 19 (Aliphatic and aromatic hydrocarbons), Group 12 (Aliphatic and aromatic tertiary alcohols and related esters constituents) and Group 10 (Alicyclic ketones, secondary alcohols and related esters flavoring compounds (Adams et al., 1996; Adams et al., 2011; Marnett et al., 2014) and assessments of other groups or individual constituents (Adams et al., 2004; Adams et al., 2005a, b, c; Adams et al., 2002; Adams et al., 1997; Adams et al., 2008; Adams et al., 1998; Adams et al., 2007; Newberne et al., 1999; Smith et al., 2002).

Step 4

Are there concerns about potential genotoxicity for any of the constituents that are present in the NFC?

If Yes, proceed to Step $4 a$.

If No, proceed to Step 5.

None of the congeneric groups that constitute these NFCs presented here raises a safety concern for genotoxicity, and therefore, all these NFCs proceed to Step 5. The FEMA Expert Panel applies a weight of evidence approach in their evaluation of genotoxic potential of flavoring ingredients (Gooderham et al., 2020b). Evaluation of the available in vitro and in vivo genotoxicity studies on Group 20 (Phenol derivatives) constituents including carvacrol, thymol and carvacrol methyl ether do not indicate a genotoxic potential for these and related compounds. These studies are described in a later section under "Biochemical and Toxicological Supporting Information Relevant to the Safety Evaluation". In addition, a review of the minor constituent profile also indicates no genotoxic concern for the congeneric groups presented. Safety assessments of relevant genotoxicity data for other congeneric groups present in the NFCs under consideration can be found in previous FEMA Expert Panel safety assessments and evaluations (Adams et al., 1996, 2008, 2011; Cohen et al., 2019; Eisenbrand et al., 2021; Marnett et al., 2014). These groups do not present a concern for genotoxicity.

Step $4 a$

Are there sufficient data to conclude that the genotoxic potential would not be a concern in vivo?

If Yes, proceed to Step 5.

If $\mathrm{No}$, additional information is required to continue the evaluation. Not required.

Step 5

Is the total intake of the congeneric group less than the TTC for the class of toxic potential assigned to the group (i.e., Class I: $1800 \mu \mathrm{g} /$ person/day, Class II: $540 \mu \mathrm{g} /$ person/day, Class III: $90 \mu \mathrm{g} /$ person/day) (Kroes et al., 2000; Munro et al., 1996)? For congeneric groups that contain members of different structural classes, the class of highest toxicological concern is selected.

If Yes, proceed to Step 7.

If No, proceed to Step 6.
The estimated intake for all reported congeneric groups presented in Thyme Oil (FEMA 3064), Thyme White Oil (FEMA 3065), Savory Summer Oil (FEMA 3013), Savory Summer Oleoresin (FEMA 3014), Savory Winter Oil (FEMA 3016), Savory Winter Oleoresin (FEMA 3017) and Origanum Oil (Extractive) (FEMA 2828) were below the TTC for their respective groups. These NFCs proceed to Step 7.

Step 6

For each congeneric group, do the data that are available from toxicological studies lead to a conclusion that no adverse effects leading to safety concerns are exerted by each group's members?

This question can commonly be answered by considering the database of relevant metabolic and toxicological data that exist for a representative member or members of the congeneric group, or the NFC itself. A comprehensive safety evaluation of the congeneric group and a sufficient margin of safety (MoS) based on the data available is to be determined on a case-bycase basis. Examples of factors that contribute to the determination of a safety margin include 1) species differences, 2) inter-individual variation, 3) the extent of natural occurrence of each of the constituents of the congeneric group throughout the food supply, and 4) the nature and concentration of constituents in related botanical genera and species. Although natural occurrence is no guarantee of safety, if exposure to the intentionally added constituent is trivial compared to intake of the constituent from consumption of food, then this should be taken into consideration in the safety evaluation (Kroes et al., 2000).

If Yes, proceed to Step 7.

If No, additional information is required to continue the evaluation. Not required.

Step 7

Calculate the mean percentage (\%) for the group of unidentified constituents of unknown structure in each NFC (as noted in Step 1) and determine the daily per capita intake $(P C I$ or $P C I \times 10)$ for this group.

Proceed to step 8

The estimated per capita intake per day for the group of unidentified constituents reported in each NFC is shown in Table 2, as well as in Appendix A.

Step 8

Using the data from Step 1, is the intake of the NFC from consumption of the food ${ }^{4}$ from which it is derived significantly greater than the intake of the NFC when used as a flavoring ingredient?

If Yes, proceed to Step 13.

If No, proceed to Step 9.

No. Thyme Oil (FEMA 3064), Thyme White Oil (FEMA 3065), Savory

Table 2

Estimated intake of unidentified constituents in the NFCs under consideration.

\begin{tabular}{lcc}
\hline Name & FEMA No. & Estimated Intake $(\mu \mathrm{g} /$ person/day) \\
\hline Origanum Oil (Extractive) & 2828 & 12 \\
Savory Summer Oil & 3013 & 0.008 \\
Savory Summer Oleoresin & 3014 & $0.01-0.03$ \\
Savory Winter Oil & 3016 & 0.02 \\
Savory Winter Oleoresin & 3017 & $0.2-0.8$ \\
Thyme Oil & 3064 & 4 \\
Thyme White Oil & 3065 & 0.06 \\
\hline
\end{tabular}

\footnotetext{
${ }^{4}$ Provided the intake of the unidentified constituents is greater from consumption of the food itself, the intake of unidentified constituents from the added NFC is considered trivial.
} 
Summer Oil (FEMA 3013), Savory Summer Oleoresin (FEMA 3014), Savory Winter Oil (FEMA 3016), Savory Winter Oleoresin (FEMA 3017) and Origanum Oil (Extractive) (FEMA 2828) are all derived from popular culinary herbs. Fresh and dried forms of these herbs are available in Western food markets and can be found growing in home gardens. However, as discussed in Step 1, data are not currently available to determine their annual consumption in food for the calculation of a consumption ratio of the estimated intake from food versus as added flavoring. As a result, the safety evaluation for these NFCs proceeds to Step 9.

Step 9

Could the unidentified constituents belong to TTC-excluded classes $?^{5}$ The excluded classes are defined as high potency carcinogens, certain inorganic substances, metals and organometallics, certain proteins, steroids, known or predicted bio-accumulators, nanomaterials, and radioactive materials (EFSA, 2016; Kroes et al., 2004).

If Yes, the NFC is not appropriate for consideration via this procedure.

If No, proceed to Step 10.

No. Based on the identified constituents, the unidentified constituents are expected to be similar low molecular weight phenol derivatives, monoterpenoid and sesquiterpenoid products of the isoprene pathway. Additionally, the NFCs under consideration are isolated via steam distillation or solvent extraction, processes that are likely to exclude the presence of constituents from TTC-excluded classes in the unidentified constituents. Savory Summer Oleoresin (FEMA 3014) and Savory Winter Oleoresin (FEMA 3017) will be composed of an essential oil fraction, similar in chemical profile to Savory Summer Oil (FEMA 3013) and Savory Winter Oil (FEMA 3016), respectively, a resinous non-volatile fraction and a food grade diluent. The production of spice oleoresins under Good Manufacturing Practices (GMP) assures that residual solvent, pesticide and metal content are below permissible acceptable levels (Food Chemical Codex, 2020) and members of the TTC-excluded classes are not expected to be present. All NFCs evaluated proceed to Step 10.

Step 10

Do the identified constituents give rise to concerns about the potential genotoxicity of the unidentified constituents?

If Yes, proceed to Step 10a.

If No, proceed to Step 11.

No, these NFCs are primarily composed of carvacrol, thymol and various monoterpene hydrocarbons, and related terpenoid intermediates of the isoprene pathway. The unidentified constituents are likely to also be products of this pathway. In Step 4, a review of genotoxicity studies indicates that these constituents show no genotoxic potential as determined by the analysis of the studies described in a later section "Biochemical and Toxicological Supporting Information Relevant to the Safety Evaluation". Similarly, there is no concern for genotoxic potential in the group of unidentified constituents in the NFCs under consideration. Proceed to Step 11.

\section{Step $10 a$}

Is the estimated intake of the group of unidentified constituents less than $0.15 \mu \mathrm{g} /$ person/day (Koster et al., 2011; Rulis, 1989)? A TTC of 0.15 $\mu \mathrm{g} /$ person/day has been proposed for potentially genotoxic substances that are not from the TTC-excluded classes (Kroes et al., 2004).

If Yes, proceed to Step 13.

\footnotetext{
${ }^{5}$ This can be based on arguments including: Expert judgement; Nature of the identified ingredients; Knowledge on the production/extraction process (see also Koster et al. (2011) and EFSA (2016)).
}

If No, proceed to Step $10 \mathrm{~b}$. Not required.

Step $10 b$

Do negative genotoxicity data exist for the NFC?

If Yes, proceed to Step 11.

If No, retain for further evaluation, which would include the collecting of data from appropriate genotoxicity tests, obtaining further analytical data to reduce the fraction of unidentified constituents, and/or considering toxicity data for other NFCs having a similar composition. When additional data are available, the NFC could be reconsidered for further evaluation.

Not required.

Step 11

Is the estimated intake of the unidentified constituents (calculated in Step 7) less than the TTC (Kroes et al., 2000; Munro et al., 1996) for Structural Class III (90 $\mu \mathrm{g} /$ person/day)? ${ }^{6}$

If Yes, proceed to Step 13.

If No, proceed to Step 12.

As shown in Table 2, estimated intakes of the fraction of unidentified constituents for each NFC are below the TTC for Structural Class III of 90 $\mu \mathrm{g} /$ person/day. Proceed to Step 13.

Step 12

Does relevant toxicological information exist that would provide an adequate margin of safety for the intake of the NFC and its unidentified constituents?

This question may be addressed by considering data for the NFC or an NFC with similar composition. It may have to be considered further on a caseby-case basis, particularly for NFCs with primarily non-volatile constituents. If Yes, proceed to Step 13.

If No, perform appropriate toxicity tests or obtain further analytical data to reduce the fraction of unidentified constituents. Resubmit for further evaluation.

Not required.

Step 13

Are there any additional relevant scientific considerations that raise a safety concern (e.g. intake by young infants and children)?

If Yes, acquire and evaluate additional data required to address the concern before proceeding to Step 14.

If No, proceed to Step 14.

No additional relevant scientific considerations that raise a safety concern were identified for any of the NFCs under consideration. Possible exposure of children and infants, given their lower body weights and the potential for differences in toxicokinetics and toxicodynamics as compared to adults, was considered for each evaluated NFC. For all NFCs under consideration, the estimated intake for each

\footnotetext{
6 The human exposure threshold of $90 \mu \mathrm{g}$ /person/day is determined from a database of NOAELs obtained from 448 subchronic and chronic studies of substances of the highest toxic potential (Structural Class III) mainly herbicides, pesticides and pharmacologically active substances (Munro et al., 1996). The 5th percentile NOAEL (lowest 5\%) was determined to be $0.15 \mathrm{mg} / \mathrm{kg}$ bw/day which upon incorporation of a 100 -fold safety factor for a $60 \mathrm{~kg}$ person yielded a human exposure threshold of the $90 \mu \mathrm{g}$ /person/day. However, no flavoring substance or food additive in this structural class exhibited a NOAEL less than $25 \mathrm{mg} / \mathrm{kg}$ bw/d. Therefore the $90 \mu \mathrm{g} /$ person/day threshold is an extremely conservative threshold for the types of substances expected in natural flavoring complexes. Additional data on other specific toxic endpoints (e.g., neurotoxicity, reproductive and endocrine disruption) support the use of this threshold value (Kroes et al., 2000).
} 
congeneric group was considerably lower than its corresponding TTC. Additionally, the estimated intakes of the unidentified constituents are well below the TTC, as shown in Table 2, with none close to the TTC threshold, indicating the approach to be protective for consumption by children. All NFCs under consideration proceed to Step 14.

\section{Step 14}

Based on the above data and considerations, the NFC can be generally recognized as safe (GRAS) under conditions of intended use as a flavoring ingredient.

Yes. The FEMA Expert Panel concludes that Thyme Oil (FEMA 3064), Thyme White Oil (FEMA 3065), Savory Summer Oil (FEMA 3013), Savory Summer Oleoresin (FEMA 3014), Savory Winter Oil (FEMA 3016), Savory Winter Oleoresin (FEMA 3017) and Origanum Oil (Extractive) (FEMA 2828) are affirmed as GRAS under conditions of intended use as a flavoring substance.

\section{Biochemical and Toxicological Supporting Information Relevant to the safety evaluation}

As shown in Fig. 2, the constituent profiles for the NFCs under consideration primarily consist of Group 20 (Phenol derivatives) constituents, principally carvacrol and thymol, Group 19 (Aliphatic and aromatic hydrocarbons) constituents and Group 12 (Aliphatic and aromatic tertiary alcohols and related esters) constituents (Adams et al., 2011; Marnett et al., 2014). Savory Summer Oil (FEMA 3013), Savory Winter Oil (FEMA 3016), Thyme Oil (FEMA 3064) and Thyme White Oil (FEMA 3065) contain small $(<5 \%)$ amounts of Group 10 (Alicyclic ketones, secondary alcohols and related esters) constituents (Adams et al., 1996). Additional minor $(<3 \%)$ amounts of Group 23 (Aliphatic and aromatic ethers) constituents and Group 3 (Aliphatic linear and branched-chain $\alpha, \beta$-unsaturated aldehydes and related alcohols, acids and esters) constituents are present in Savory Winter Oil (FEMA 3016) and Thyme Oil (FEMA 3064) (Adams et al., 2008).

Below, toxicity and genotoxicity studies for Group 20 (Phenol derivatives) constituents carvacrol, thymol and carvacrol methyl ether and for the NFCs under consideration that support the safety evaluation are described. A summary of the genotoxicity studies presented is provided in Table 3.

\subsection{Group 20 (Phenol derivatives) constituents}

\subsubsection{Carvacrol (FEMA No. 2245)}

Genotoxicity. In an OECD and GLP guideline-compliant mutagenicity study, Salmonella typhimurium strains TA98, TA100, TA1535 and TA1537 and Escherichia coli strain WP2uvrA were treated with carvacrol in two independent assays up to $5000 \mu \mathrm{g} /$ plate with and without Aroclor 1254-induced rat liver S9. Under the conditions tested, there were no increases in the frequency of revertant colonies as a result of incubation with carvacrol (Bhalli, 2014). Another mutagenicity study conducted following the principles of the OECD guideline tested carvacrol in S. typhimurium strains TA97a, TA98, TA100, TA102 and TA104 up to a maximum concentration of $187 \mu \mathrm{g} /$ plate. In the presence and absence of Aroclor 1254-induced rat liver S9 in strain TA98 and in the absence of S9 in TA97a, carvacrol caused a slightly greater than 2 fold increase in revertant frequency but in a non-concentration-dependent manner (Llana-Ruiz-Cabello et al., 2014b). Cytotoxicity was not observed up to $460 \mu \mathrm{M}$, the highest concentration tested. However, the lack of a concentration response in these strains precludes the determination of a positive result for carvacrol based on the responses observed in strains TA97a and TA98 (Gooderham et al., 2020b; OECD, 1997). In the absence of a repeat assay demonstrating a concentration response, this study is not helpful to the safety evaluation of NFCs containing carvacrol.

In other Ames assays, carvacrol was tested in $S$. typhimurium strains TA98 and TA100 yielding mixed results (Ipek et al., 2005; Kono et al., 1995; Stammati et al., 1999). In one study, carvacrol was tested at $0.01-1.0 \mu \mathrm{L} /$ plate in the presence and absence of a 3-methylcholanthrene-induced rat liver $\$ 9$ metabolic activation system. Carvacrol increased the number of revertant colonies in TA98, with and without S9, and in TA100, only without S9 (Ipek et al., 2005). While statistically significant ( $\mathrm{p}<0.001$ ), these increases were not concentration-dependent, with higher concentrations displaying colony counts comparable to the solvent and untreated controls in the absence of cytotoxicity. In another study, carvacrol did not induce mutagenicity in $S$. typhimurium strains TA98 and TA100 at concentrations of 8 or $16 \mu \mathrm{g} / \mathrm{mL}$ in the presence or absence of S9 metabolic activation (Kono et al., 1995). Similarly, carvacrol, at concentrations of 94, 188 and $376 \mu \mathrm{g} /$ plate, was not mutagenic in strains TA98 and TA100 in assays with and without phenobarbital-induced rat liver S9 metabolic activation system (Stammati et al., 1999).

There was no indication of mutagenic potential when carvacrol was tested in a forward mutation assay using mouse lymphoma L5178Y/TK ${ }^{ \pm}$ cells. Carvacrol did not increase the number of forward mutations after 4 or $24 \mathrm{~h}$ at concentrations ranging from 62.5 to $1500 \mu \mathrm{M}$ in the absence of metabolic activation (Maisanaba et al., 2015b). Carvacrol was also negative for genotoxicity in an in vitro sister chromatid exchange (SCE) study when tested in human lymphocytes at concentrations up to 5 $\mu \mathrm{L} / \mathrm{mL}$ (Ipek et al., 2003). Due to a lack of understanding of the underlying mechanism(s) of action of the SCE assay, it was removed from the OECD library of standardized assays in 2014 (OECD, 2015) and its relevance to the safety evaluation cannot be assessed (Gooderham et al., 2020b).

In an in vitro comet assay to detect DNA damage, carvacrol was tested in human peripheral blood lymphocytes (HPBL) at concentrations of 0.0005-2 mM (Aydin et al., 2005b, a). Cytotoxicity was determined using the trypan blue exclusion test, which indicated cell viability of greater than $90 \%$ at the tested concentrations. A significant increase in DNA damage was measured at concentrations of $\geq 0.1 \mathrm{mM}$ carvacrol. In another in vitro comet assay (Horvathova et al., 2007), carvacrol was tested in human myelogenous leukemia K562 cells at concentrations of $100 \mu \mathrm{M}-200 \mu \mathrm{M}$. Cytotoxicity was determined using the trypan blue exclusion test, which indicated cell viability of greater than $50 \%$ at the tested concentrations. At both concentrations, treatment with carvacrol showed a slight but statistically significant increase in DNA damage. In a third in vitro comet assay, carvacrol did not cause DNA damage in V79 Chinese hamster lung fibroblast cells at concentrations up to $25 \mu \mathrm{M}$, nor was cytotoxicity observed at these concentrations (Undeger et al., 2009). A fourth study evaluated carvacrol in human carcinoma Caco-2 cells and HepG2 cells for its potential to cause DNA damage using the in vitro comet assay. When tested up to an overall maximum concentration of $200 \mu \mathrm{M}$ (based on cytotoxicity experiments), carvacrol presented \% tail DNA values in both cell lines that were comparable to the negative control values (Slamenova et al., 2007). In a fifth study, carvacrol was tested at concentrations up to $460 \mu \mathrm{M}$ in Caco- 2 cells in the in vitro comet assay. No increase in DNA damage was detected when Caco- 2 cells were exposed to carvacrol for 24 or $48 \mathrm{~h}$ in the standard comet assay and an Endo III enzyme modified assay. In a formamidopyrimidine glycosylase (FPG) enzyme modified comet assay, $460 \mu \mathrm{M}$ carvacrol induced DNA damage when incubated for $48 \mathrm{~h}$ in Caco-2 cells (Llana-Ruiz-Cabello et al., 2014b). The cytotoxicity of carvacrol is Caco-2 cells was assessed using the protein content (PC) assay, the supravital dye neutral red (NR) cellular uptake assay and the 3-(4,5-dimethylthiazol-2-yl)-5-(3-carboxymethoxyphenyl)-2-(4-sulfophenyl)-2H-tetrazolium salt (MTS) reduction assay (Llana-Ruiz-Cabello et al., 2014a). In incubations of Caco-2-cells with carvacrol, the $\mathrm{EC}_{50}$ values (the concentration that modified each biomarker by $50 \%$ versus controls) for the three cytotoxicity assays ranged from 460 to $543 \mu \mathrm{M}$ in $24 \mathrm{~h}$ experiments and $340-377 \mu \mathrm{M}$ in $48 \mathrm{~h}$ experiments. Based on these determinations of 
Table 3

Summary of genotoxicity studies for carvacrol, thymol, carvacrol methyl ether and NFCs under consideration.

\begin{tabular}{|c|c|c|c|c|}
\hline Name of Substance Tested & Test Type (System) & Doses Tested & Results & Reference \\
\hline \multicolumn{5}{|c|}{ a. Group 20 (Phenol derivatives) Constituents - In vitro studies } \\
\hline Carvacrol & Reverse mutation in $S$. typhimurium ${ }^{\text {a }}$ & $8,16 \mu \mathrm{g} / \mathrm{mL}$ & Negative $^{a}$ & Kono et al. (1995) \\
\hline Carvacrol & Reverse mutation in $S$. typhimurium ${ }^{\text {a }}$ & $94,188,376 \mu \mathrm{g} /$ plate & Negative $^{a}$ & Stammati et al. (1999) \\
\hline Carvacrol & Reverse mutation in $S$. typhimurium ${ }^{\text {a }}$ & $0.01-1.0 \mu \mathrm{L} /$ plate & Positive ${ }^{\mathrm{b}}$ & Ipek et al. (2005) \\
\hline Carvacrol & Reverse mutation in $S$. typhimurium ${ }^{\mathrm{a}}$ & $29-460 \mu \mathrm{M}$ & Positive $^{c}$ & Llana-Ruiz-Cabello et al. (2014b) \\
\hline Carvacrol & Reverse mutation in S. typhimurium and E. coli ${ }^{\mathrm{a}}$ & $\begin{array}{l}\left.5-5000 \mu \mathrm{g} / \text { plate }^{\mathrm{a}} \text { (test } 1\right) \\
31.3-2000 \mu \mathrm{g} / \text { plate }^{\mathrm{a}} \text { (test 2) }\end{array}$ & Negative $^{a}$ & Bhalli (2014) \\
\hline Carvacrol & Forward mutation in mouse lymphoma L5178Y $/ \mathrm{Tk}^{ \pm}$cells & $62.5-1500 \mu \mathrm{M}$ & Negative & Maisanaba et al. (2015b) \\
\hline Carvacrol & Sister chromatid exchange in human lymphocytes & $0.1,0.5,1,5 \mu \mathrm{L} / \mathrm{mL}$ & Negative & Ipek et al. (2003) \\
\hline Carvacrol & In vitro comet assay in human lymphocytes & $0.0005-2 \mathrm{mM}$ & Positive & (Aydin et al., 2005b, a) \\
\hline Carvacrol & In vitro comet assay in human leukemic K562 cells & $100,150,200 \mu \mathrm{M}$ & Positive & Horvathova et al. (2007) \\
\hline Carvacrol & In vitro comet assay in Caco- 2 cells & $50,100,150,200,300 \mu \mathrm{M}$ & Negative & Slamenova et al. (2007) \\
\hline Carvacrol & In vitro comet assay in HepG2 cells & $25,50,100,150,200 \mu \mathrm{M}$ & Negative & Slamenova et al. (2007) \\
\hline Carvacrol & In vitro comet assay in Chinese hamster V79 cells & $1,5,25 \mu \mathrm{M}$ & Negative & Undeger et al. (2009) \\
\hline Carvacrol & In vitro comet assay in Caco- 2 cells & $115,230,460 \mu \mathrm{M}$ & Negative $^{\mathrm{d}}$ & Llana-Ruiz-Cabello et al. (2014b) \\
\hline Carvacrol & In vitro chromosomal aberration in human lymphocytes & $10 \mathrm{mg} / \mathrm{L}$ to $200 \mathrm{mg} / \mathrm{L}$ & Negative & Turkez and Aydin (2013) \\
\hline Carvacrol & In vitro micronucleus in human lymphocytes & $10 \mathrm{mg} / \mathrm{L}$ to $200 \mathrm{mg} / \mathrm{L}$ & Negative & Turkez and Aydin (2013) \\
\hline Carvacrol & In vitro micronucleus in human lymphocytes ${ }^{\mathrm{a}}$ & $\begin{array}{l}25-122 \mu \mathrm{g} / \mathrm{mL}^{\mathrm{e}, \mathrm{g}} \\
25-85 \mu \mathrm{g} / \mathrm{mL}^{\mathrm{e}, \mathrm{h}} \\
3.25-50 \mu \mathrm{g} / \mathrm{mL}^{\mathrm{f} . \mathrm{g}}\end{array}$ & Negative $^{a}$ & Roy and Jois (2012a) \\
\hline Carvacrol & $\begin{array}{l}\text { In vitro micronucleus in mouse lymphoma } \mathrm{L} 5178 \mathrm{Y} / \mathrm{Tk}^{ \pm} \\
\text {cells }^{\mathrm{a}}\end{array}$ & $44-700 \mu \mathrm{M}$ & Negative $^{\mathrm{i}}$ & Maisanaba et al. (2015b) \\
\hline Thymol & Reverse mutation in $S$. typhimurium ${ }^{\mathrm{a}}$ & $450 \mu \mathrm{g} /$ plate & Negative $^{a}$ & Florin et al. (1980) \\
\hline Thymol & Reverse mutation in $S$. typhimurium ${ }^{\mathrm{a}}$ & Unspecified & Negative $^{\text {a }}$ & Azizan and Blevins (1995) \\
\hline Thymol & Reverse mutation in $S$. typhimurium ${ }^{\text {a }}$ & $94,188,376 \mu \mathrm{g} /$ plate & Negative $^{a}$ & Stammati et al. (1999) \\
\hline Thymol & Reverse mutation in S. typhimurium ${ }^{\text {a }}$ & $\begin{array}{l}8-5000 \mu \mathrm{g} / \text { plate (test } 1 \text { ) } \\
6-192 \mu \mathrm{g} / \text { plate (test } 2 \text { ) }\end{array}$ & Negative $^{a}$ & ECHA (1989) \\
\hline Thymol & Reverse mutation in $S$. typhimurium ${ }^{\mathrm{a}}$ & $15.6-250 \mu \mathrm{M}$ & Negative $^{a}$ & Llana-Ruiz-Cabello et al. (2014b) \\
\hline Thymol & Reverse mutation in $S$. typhimurium and $E$. coli ${ }^{\mathrm{a}}$ & $15.6-500 \mu \mathrm{g} /$ plate & Negative $^{a}$ & JMHLW (1996d) \\
\hline Thymol & Forward mutation in Chinese hamster V79 fibroblasts ${ }^{\mathrm{a}}$ & $\begin{array}{l}2.8-45 \mu \mathrm{g} / \mathrm{mL}^{\mathrm{g}} \text { (test } 1 \text { ) } \\
11.3-90 \mu \mathrm{g} / \mathrm{mL}^{\text {h }} \text { (test } 1 \text { ) } \\
5-50 \mu \mathrm{g} / \mathrm{mL}^{\mathrm{g}} \text { (test } 2 \text { ) } \\
40-110 \mu \mathrm{g} / \mathrm{mL}^{\mathrm{h}} \text { (test } 2 \text { ) }\end{array}$ & Negative $^{a}$ & ECHA (2010) \\
\hline Thymol & Forward mutation in mouse lymphoma L5178Y $/ \mathrm{Tk}^{ \pm}$cells & $8-250 \mu \mathrm{M}$ & Negative & Maisanaba et al. (2015b) \\
\hline Thymol & Sister chromatid exchange in human lymphocytes & $25,50,75,100 \mu \mathrm{g} / \mathrm{mL}$ & Positive $^{j}$ & $\begin{array}{l}\text { Buyukleyla and Rencuzogullari } \\
\text { (2009) }\end{array}$ \\
\hline Thymol & Sister chromatid exchange in Syrian hamster embryo cells & $0.3-30 \mu \mathrm{g} / \mathrm{mL}$ & Positive & Fukuda (1987) \\
\hline Thymol & $\begin{array}{l}\text { Unscheduled DNA synthesis in Syrian hamster embryo } \\
\text { cells }^{\mathrm{a}}\end{array}$ & $0.3-10 \mu \mathrm{g} / \mathrm{mL}$ & $\begin{array}{l}\text { Negative }^{g} \\
\text { Positive }^{\text {h }}\end{array}$ & Fukuda (1987) \\
\hline Thymol & In vitro comet assay in human lymphocytes & $0.75-300 \mu \mathrm{g} / \mathrm{mL}$ & Positive & (Aydin et al., 2005b, a) \\
\hline Thymol & In vitro comet assay in human leukemic K562 cells & $100,200,300,400 \mu \mathrm{M}$ & Negative & Horvathova et al. (2007) \\
\hline Thymol & In vitro comet assay in Caco-2 cells & $100,250,450,600 \mu \mathrm{M}$ & Negative & Slamenova et al. (2007) \\
\hline Thymol & In vitro comet assay in HepG2 cells & $100,250,450,500 \mu \mathrm{M}$ & Negative & Slamenova et al. (2007) \\
\hline Thymol & In vitro comet assay in Chinese hamster V79 cells & $150,750,3750 \mu \mathrm{g} / \mathrm{mL}$ & Positive & Undeger et al. (2009) \\
\hline Thymol & In vitro comet assay in Caco- 2 cells & $62.5,125,250 \mu \mathrm{M}$ & Negative & Llana-Ruiz-Cabello et al. (2014b) \\
\hline Thymol & $\begin{array}{l}\text { In vitro chromosomal aberration in Chinese hamster lung } \\
\text { cells }^{\mathrm{a}}\end{array}$ & $20,40,80 \mu \mathrm{g} / \mathrm{mL}$ & $\begin{array}{l}\text { Positive }{ }^{e, h} \\
\text { Negative }^{e, f, g}\end{array}$ & $\begin{array}{l}\text { (JMHLW, 1996b; Kusakabe et al., } \\
\text { 2002) }\end{array}$ \\
\hline Thymol & $\begin{array}{l}\text { In vitro chromosomal aberration in Syrian hamster embryo } \\
\text { cells }^{\mathrm{a}}\end{array}$ & $130,260,390 \mu \mathrm{M}$ & $\begin{array}{l}\text { Positive }^{h} \\
\text { Negative }^{g}\end{array}$ & Hikiba et al. (2005) \\
\hline Thymol & In vitro chromosomal aberration in human lymphocytes & $25,50,75,100 \mu \mathrm{g} / \mathrm{mL}$ & Positive & $\begin{array}{l}\text { Buyukleyla and Rencuzogullari } \\
\text { (2009) }\end{array}$ \\
\hline Thymol & In vitro micronucleus in human lymphocytes ${ }^{\mathrm{a}}$ & $25,50,75,100 \mu \mathrm{g} / \mathrm{mL}$ & Positive & $\begin{array}{l}\text { Buyukleyla and Rencuzogullari } \\
\text { (2009) }\end{array}$ \\
\hline Thymol & In vitro micronucleus in human lymphocytes ${ }^{\mathrm{a}}$ & $\begin{array}{l}15-135 \mu \mathrm{g} / \mathrm{mL}^{\mathrm{a}, \mathrm{e}} \\
0.8-98 \mu \mathrm{g} / \mathrm{mL}^{\mathrm{f}, \mathrm{h}}\end{array}$ & Negative $^{\mathrm{a}}$ & Roy and Jois (2012b) \\
\hline Thymol & $\begin{array}{l}\text { In vitro micronucleus in mouse lymphoma } \mathrm{L} 5178 \mathrm{Y} / \mathrm{Tk}^{ \pm} \\
\text {cells }^{\mathrm{a}}\end{array}$ & $16-250 \mu \mathrm{M}$ & Negative $^{a}$ & Maisanaba et al. (2015b) \\
\hline Carvacrol methyl ether & Reverse mutation in $S$. typhimurium and $E$. coli $^{\mathrm{a}}$ & $1.5-5000 \mu \mathrm{g} /$ plate & Negative $^{a}$ & Dakoulas (2016) \\
\hline \multirow[t]{3}{*}{ Carvacrol methyl ether } & In vitro micronucleus in human lymphocytes ${ }^{\mathrm{a}}$ & $10-150 \mu \mathrm{g} / \mathrm{mL}^{\mathrm{e}, \mathrm{g}}$ & Negative $^{a}$ & Roy (2016) \\
\hline & & $25-175 \mu \mathrm{g} / \mathrm{mL}^{\mathrm{e}, \mathrm{h}}$ & & \\
\hline & & $5-60 \mu \mathrm{g} / \mathrm{mL}^{\mathrm{f}, \mathrm{h}}$ & & \\
\hline \multicolumn{5}{|c|}{ b. Group 20 (Phenol derivatives) Constituents - In vivo studies } \\
\hline Carvacrol & $\begin{array}{l}\text { In vivo chromosomal aberration in male Sprague-Dawley } \\
\text { rats (hepatocytes) }\end{array}$ & $30,60 \mathrm{mg} / \mathrm{kg}$ bw/day & Negative & Slamenova et al. (2011) \\
\hline Carvacrol & $\begin{array}{l}\text { In vivo micronucleus in Sprague-Dawley rats (bone marrow } \\
\text { erythrocytes) }\end{array}$ & $81,256,810 \mathrm{mg} / \mathrm{kg}$ bw & Negative & Llana-Ruiz-Cabello et al. (2016) \\
\hline Carvacrol & In vivo comet in Sprague-Dawley rats (stomach and liver) & $81,256,810 \mathrm{mg} / \mathrm{kg}$ bw & Negative & Llana-Ruiz-Cabello et al. (2016) \\
\hline Thymol & In vivo micronucleus in $\mathrm{BDF}_{1}$ mice (femoral bone marrow) & $312,625,1250 \mathrm{mg} / \mathrm{kg}$ bw & Negative & JMHLW (1996c) \\
\hline Thymol & In vivo micronucleus in ICR mice (femoral bone marrow) & $275,550,1100 \mathrm{mg} / \mathrm{kg}$ bw & Negative & ECHA (1995) \\
\hline \multicolumn{5}{|c|}{ c. Natural Flavor Complexes - In vitro studies } \\
\hline Origanum extract & Reverse mutation in $S$. typhimurium & $10 \mathrm{mg} /$ plate & Positive $^{\mathrm{k}}$ & Mahmoud et al. (1992) \\
\hline Origanum oil & Reverse mutation in S. typhimurium ${ }^{\text {a }}$ & $0.07,0.15,0.3 \mu \mathrm{L} /$ plate & Negative $^{\mathrm{a}}$ & Zani et al. (1991) \\
\hline Origanum oil & Rec assay in $B$. subtilis & $10,30 \mu \mathrm{L} /$ disk & Negative & Zani et al. (1991) \\
\hline Savory summer oil & Reverse mutation in $S$. typhimurium ${ }^{\text {a }}$ & $0.07,0.15,0.3 \mu \mathrm{L} /$ plate & Negative $^{a}$ & Zani et al. (1991) \\
\hline
\end{tabular}


Table 3 (continued)

\begin{tabular}{|c|c|c|c|c|}
\hline Name of Substance Tested & Test Type (System) & Doses Tested & Results & Reference \\
\hline Savory summer oil & Rec assay in $B$. subtilis & $10,30 \mu \mathrm{L} /$ disk & Negative & Zani et al. (1991) \\
\hline Savory winter oil & Reverse mutation in $S$. typhimurium ${ }^{\mathrm{a}}$ & $0.07,0.15,0.3 \mu \mathrm{L} /$ plate & Negative $^{a}$ & Zani et al. (1991) \\
\hline Savory winter oil & Rec assay in $B$. subtilis & $10,30 \mu \mathrm{L} /$ disk & Negative & Zani et al. (1991) \\
\hline $\begin{array}{l}\text { Savory oil (unspecified } \\
\text { type) }\end{array}$ & Reverse mutation in $S$. typhimurium ${ }^{\mathrm{a}}$ & $0.1 \mu \mathrm{g} /$ plate & Negative $^{\mathrm{a}}$ & Ishidate et al. (1988) \\
\hline $\begin{array}{l}\text { Savory oil (unspecified } \\
\text { type) }\end{array}$ & Rec assay in B. subtilis ${ }^{\mathrm{a}}$ & $1.5,4 \mathrm{mg} / \mathrm{disk}$ & Positive $^{\mathrm{a}}$ & Ishidate et al. (1988) \\
\hline $\begin{array}{l}\text { Savory oil (unspecified } \\
\text { type) }\end{array}$ & $\begin{array}{l}\text { In vitro chromosomal aberration in Chinese hamster lung } \\
\text { cells }\end{array}$ & $0.1 \mathrm{mg} / \mathrm{mL}$ & $\begin{array}{l}\text { Positive }^{\mathrm{h}} \\
\text { Negative }^{g}\end{array}$ & Ishidate et al. (1988) \\
\hline $\begin{array}{l}\text { Savory extract (unspecified } \\
\text { type) }\end{array}$ & Reverse mutation in $S$. typhimurium ${ }^{\mathrm{a}}$ & $10,30,50 \mathrm{mg} /$ plate & Negative $^{a}$ & Namiki et al. (1984) \\
\hline Thyme oil & Reverse mutation in $S$. typhimurium ${ }^{\mathrm{a}}$ & $0.25,0.5,1 \mu \mathrm{L} /$ plate & Negative $^{a}$ & Zani et al. (1991) \\
\hline Thyme oil & Reverse mutation in $S$. typhimurium & $5,10 \mathrm{ng} / \mathrm{plate}$ & Positive & Sivaswamy et al. (1991) \\
\hline Thyme oil & Reverse mutation in $S$. typhimurium ${ }^{\mathrm{a}}$ & $93,185,463 \mu \mathrm{g} /$ plate & Negative $^{a}$ & De Martino et al. (2009) \\
\hline Thyme oil & Reverse mutation in $S$. typhimurium ${ }^{\mathrm{a}}$ & $50-2000 \mu \mathrm{g} / \mathrm{mL}$ & Negative $^{a}$ & Shoeibi et al. (2009) \\
\hline Thyme oil & Rec assay in $B$. subtilis & $2 \mathrm{mg} / \mathrm{disk}$ & $\begin{array}{l}\text { Positive }^{\mathrm{d}} \\
\text { Negative }^{\mathrm{e}}\end{array}$ & Ueno et al. (1984) \\
\hline Thyme oil & Rec assay in $B$. subtilis & $10,30 \mu \mathrm{L} /$ disk & Negative & Zani et al. (1991) \\
\hline Thyme oil & In vitro comet in human embryo lung 12,469 cells & $0.0025-0.05 \mu \mathrm{L} / \mathrm{mL}$ & Negative & Puskarova et al. (2017) \\
\hline Thyme oil & $\begin{array}{l}\text { In vitro chromosomal aberration in Chinese hamster lung } \\
\text { cells }\end{array}$ & $0.05 \mathrm{mg} / \mathrm{mL}$ & Negative & Ishidate et al. (1984) \\
\hline Thyme extract & Reverse mutation in $S$. typhimurium ${ }^{\mathrm{a}}$ & $10,30,50 \mathrm{mg} /$ plate & Negative $^{a}$ & Namiki et al. (1984) \\
\hline \multicolumn{5}{|c|}{ d. Natural Flavor Complexes - In vivo studies } \\
\hline Oregano oil & In vivo micronucleus in Wistar rats (femoral bone marrow) & $\begin{array}{l}50,100,200 \mathrm{mg} / \mathrm{kg} \text { bw/day ( } 90 \\
\text { days) }\end{array}$ & Negative & Llana-Ruiz-Cabello et al. (2018) \\
\hline Oregano oil & In vivo comet assay Wistar rats (blood, stomach, liver) & $\begin{array}{l}50,100,200 \mathrm{mg} / \mathrm{kg} \text { bw/day ( } 90 \\
\text { days) }\end{array}$ & Negative & Llana-Ruiz-Cabello et al. (2018) \\
\hline
\end{tabular}

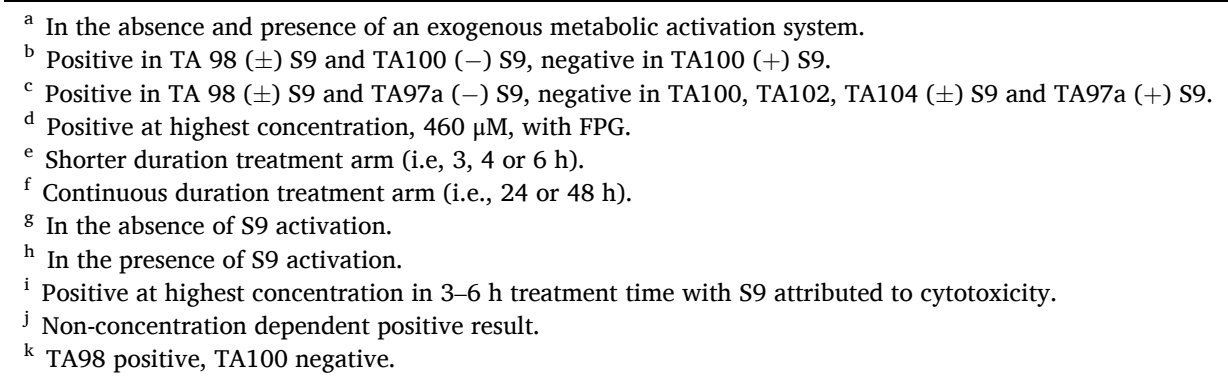

cytotoxicity, the positive result for carvacrol in the $48 \mathrm{~h}$ FPG enzyme modified comet assay at $460 \mu \mathrm{M}$ carvacrol is attributed to cytotoxicity of the test substance. The in vitro comet assay lacks a standardized procedure for the performance and evaluation of results. As a result, the relevance of the results from the in vitro comet assay to the safety evaluation of NFCs containing carvacrol cannot be assessed (Gooderham et al., 2020b).

In an in vitro micronucleus assay, carvacrol was tested in mouse lymphoma L5178Y $/ \mathrm{TK}^{ \pm}$cells at concentrations ranging from 44 to 700 $\mu \mathrm{M}$ (Maisanaba et al., 2015b). In a $24 \mathrm{~h}$ exposure test in the absence of S9 metabolic activation system, carvacrol did not induce micronuclei formation at concentrations up to $700 \mu \mathrm{M}$. In a $4 \mathrm{~h}$ exposure test in the presence of S9, a statistically significant increase in the formation of micronuclei was reported only at the highest concentration tested, 700 $\mu \mathrm{M}$. Because the cell viability was reduced by more than $50 \%$ at $700 \mu \mathrm{M}$, the small induction of micronuclei observed is attributed to the cytotoxicity of carvacrol at this concentration. In an OECD and GLP guideline-compliant in vitro micronucleus assay, carvacrol was tested in HPBL (Roy and Jois, 2012a). Carvacrol was tested at concentrations of $25-85 \mu \mathrm{g} / \mathrm{mL}$ in $4 \mathrm{~h}$ treatments in the presence of S9 metabolic activation system derived from Aroclor 1254-induced rat liver, at concentrations of $25-122 \mu \mathrm{g} / \mathrm{mL}$ in $4 \mathrm{~h}$ treatments in the absence of S9 and at concentrations of $3.25-50 \mu \mathrm{g} / \mathrm{mL}$ in $24 \mathrm{~h}$ treatments in the absence of S9. Cytotoxicity, measured by the cytokinesis-block proliferation index (CBPI), was significant at concentrations $\geq 150 \mu \mathrm{g} / \mathrm{mL}$ in all three test groups. There was no induction of micronuclei in the $4 \mathrm{~h}$ treatment with S9 or the $24 \mathrm{~h}$ treatment in the absence of S9. In the $4 \mathrm{~h}$ treatment in the absence of S9, a statistically significant increase in micronuclei frequency was reported at $122 \mu \mathrm{g} / \mathrm{mL}$, the highest concentration scored for micronuclei. Despite the statistical significance of this result, the frequency of micronuclei was within the laboratory's historical negative control range for this test and, therefore, carvacrol did not meet the OECD criteria for a positive outcome and was considered negative for micronucleus induction (Roy and Jois, 2012a).

Carvacrol was tested in an in vitro micronucleus induction assay and an in vitro chromosomal aberration (CA) assay in HPBL (Turkez and Aydin, 2013). Cell cultures treated at concentrations of 10, 25, 50, 75, 100,150 and $200 \mu \mathrm{g} / \mathrm{mL}$ carvacrol. For the in vitro micronucleus assay, lymphocytes were treated with carvacrol for $72 \mathrm{~h}$ in the absence of metabolic activation. A minimum of 1000 binucleated lymphocytes were scored for the presence of micronuclei. No significant increase in micronuclei formation, compared to the control, was observed upon treatment with carvacrol. For the in vitro CA assay, lymphocytes were treated with carvacrol for $72 \mathrm{~h}$ in the absence of metabolic activation. For each treatment, 30 metaphases were analyzed. No increase in cells with CA upon treatment with carvacrol, compared to the negative control, was observed.

In an in vivo CA study, groups of male Sprague-Dawley rats were provided carvacrol at concentrations resulting in dose levels of 30 or 60 $\mathrm{mg} / \mathrm{kg}$ bw/day in the drinking water for 7 consecutive days. After the treatment period, the hepatocytes were collected and analyzed for the presence of CA. Carvacrol did not cause a statistically significant increase in the frequency of CA when compared to the concurrent control group (Slamenova et al., 2011).

An OECD guideline-compliant combined in vivo micronucleus and alkaline comet assay was conducted on carvacrol. Male and female Wistar rats were provided three consecutive doses of 81,256 or $810 \mathrm{mg} /$ $\mathrm{kg}$ bw by oral gavage (Llana-Ruiz-Cabello et al., 2016). Analysis of the 
mucosa of the glandular stomach and liver tissues in rats at each dose level confirmed the presence of carvacrol in these tissues at all dose levels. The femoral bone marrow and stomach and liver tissue were examined for micronucleus and comet endpoints. Carvacrol did not cause an increase in the frequency of micronucleated polychromatic erythrocytes in the bone marrow at any of the tested doses. Slight cytotoxicity, characterized by a decrease in the ratio of polychromatic to normochromatic erythrocytes relative to the control, was reported in males of the mid-dose group and females of the high-dose group. No indication of DNA damage was observed in the liver or stomach of carvacrol-treated rats. Additionally, histopathology did not reveal any treatment-related adverse effects. Based on these findings, carvacrol was determined to be negative for genotoxicity when tested up to the maximum tolerated dose (Llana-Ruiz-Cabello et al., 2016).

In summary, mutagenicity and genotoxicity assays for carvacrol were generally negative with a few positive results. Carvacrol was not mutagenic in an OECD guideline-compliant Ames test as well as other non-guideline Ames assays (Bhalli, 2014; Kono et al., 1995; Stammati et al., 1999). In two Ames assays, a non-concentration dependent increase in revertant frequency was observed with treatment of carvacrol, but in the absence of a repeat assay demonstrating a dose response, these results are not considered positive for mutagenicity and are not relevant to the safety evaluation (Ipek et al., 2005; Llana-Ruiz-Cabello et al., 2014b). Carvacrol was also found to be negative for genotoxicity in several in vitro studies including a forward mutation study in mouse lymphoma L5178Y/TK ${ }^{ \pm}$cells, an SCE study in human lymphocytes, micronucleus assays in HPBL and mouse lymphoma L5178Y $/ \mathrm{TK}^{ \pm}$cells and a CA assay in HPBL (Ipek et al., 2003; Maisanaba et al., 2015a; Roy and Jois, 2012a; Turkez and Aydin, 2013). In the in vitro comet assays, both positive and negative results have been reported for carvacrol in a variety of cell lines. However, because positive results were often accompanied by cytotoxicity and because standard protocols for the performance and evaluation of results of this assay have not been established, the results of these assays are not helpful to the safety evaluation of carvacrol (Gooderham et al., 2020b). Two in vivo genotoxicity assays were reviewed for carvacrol. An in vivo CA assay examining the hepatocytes in male rats administered carvacrol in the diet for 7 days at concentrations up to $60 \mathrm{mg} / \mathrm{kg}$ bw/day was negative (Slamenova et al., 2011) and an OECD guideline-compliant in vivo combined micronucleus and comet study in rats reported no induction of DNA damage in the tissues of the liver and stomach and no induction of micronuclei in the femoral bone marrow (Llana-Ruiz-Cabello et al., 2016). Applying a weight of evidence approach (Gooderham et al., $2020 \mathrm{~b})$, the negative results of the OECD guideline Ames and in vivo micronucleus and alkaline comet assay in rats in which tissue exposure of carvacrol was confirmed, as well as negative results in several in vitro assays provide convincing evidence for a lack of in vivo genotoxic potential for carvacrol.

\subsubsection{Thymol (FEMA no. 3066)}

7.1.2.1. Genotoxicity. Several Ames mutagenicity assays have been conducted for thymol using $S$. typhimurium strains TA97, TA98, TA100, TA102, TA104, TA1535 and/or TA1537 in the presence and absence of S9 metabolic activation. All of the studies found thymol to be negative for mutagenicity up to the maximum tested concentration of $5000 \mu \mathrm{g} /$ plate (Azizan and Blevins, 1995; ECHA, 1989; Florin et al., 1980; Llana-Ruiz-Cabello et al., 2014b; Stammati et al., 1999). An OECD guideline-compliant reverse mutagenicity assay confirmed the lack of mutagenic potential of thymol observed in the studies above. Thymol was tested up to cytotoxic concentrations and did not cause any increases in the number of revertant colonies in $S$. typhimurium strains TA98, TA100, TA1535 and TA1537 and E. coli WP2uvrA in the presence or absence of S9 metabolic activation (JMHLW, 1996d). Similarly, two forward mutation studies using Chinese hamster V79 cells and mouse lymphoma $\mathrm{L} 5178 \mathrm{Y} / \mathrm{TK}^{ \pm}$cells concluded thymol was non-mutagenic in assays with shorter duration and continuous treatments with or without S9 (ECHA, 2010; Maisanaba et al., 2015b).

Several in vitro comet assays assessed the potential for thymol to induce DNA damage in primary cell lines, including V79 fibroblasts and human lymphocytes. In HPBL, thymol was tested at a range of $0.75 \mu \mathrm{g} /$ $\mathrm{mL}$ to $300 \mu \mathrm{g} / \mathrm{mL}$ in the absence of $\mathrm{S} 9$ only. At concentrations of $30 \mu \mathrm{g} /$ $\mathrm{mL}$ and greater, statistically significant increases in the number of DNA damaged lymphocytes were reported (Aydin et al., 2005b, a). In three cell lines, K562, Caco-2 and HepG2, thymol did not induce single-strand DNA breaks when tested up to concentrations of $600 \mu \mathrm{M}$ (Horvathova et al., 2007; Llana-Ruiz-Cabello et al., 2014b; Slamenova et al., 2007). Thymol was tested in another in vitro comet assay in V79 Chinese hamster lung fibroblast cells at concentrations of approximately 150, 750 and $3750 \mu \mathrm{g} / \mathrm{mL}$. At the highest concentration of $3750 \mu \mathrm{g} / \mathrm{mL}$, thymol induced an increase in the tail moment of V79 cells (Undeger et al., 2009). As noted previously for in vitro comet assays, the assay lacks a standardized procedure for the performance and evaluation of results. As a result, the relevance of the results from the in vitro comet assay to the safety evaluation of NFCs containing thymol cannot be assessed (Gooderham et al., 2020b).

In a CA assay in Syrian hamster embryo (SHE) cells, thymol was concluded to be genotoxic in the presence of $S 9$ metabolic activation. Increases in aberrant metaphase cells $(\mathrm{p}<0.05)$ were observed at 130 , 260 and $360 \mu \mathrm{M}$ in treatments with S9 but not at 130, 260, 390 and 520 $\mu \mathrm{M}$ in treatments without $\mathrm{S} 9$ metabolic activation (Hikiba et al., 2005). Positive results were also reported for thymol in an SCE assay in SHE cells at concentrations of $0.3-30 \mu \mathrm{g} / \mathrm{mL}$ and in an unscheduled DNA synthesis (UDS) assay at concentrations of $0.3-10 \mu \mathrm{g} / \mathrm{mL}$, with metabolic activation. Thymol was negative in a UDS assay at concentrations of $0.3-10 \mu \mathrm{g} / \mathrm{mL}$ in the absence of metabolic activation (Fukuda, 1987). In another CA assay in SHE cells, thymol was concluded to be genotoxic in the presence of $S 9$ metabolic activation. Increases in aberrant metaphase cells $(\mathrm{p}<0.05)$ were observed at 130,260 and $360 \mu \mathrm{M}$ in treatments with S9 but not at 130, 260, 390 and $520 \mu \mathrm{M}$ in treatments without S9 metabolic activation (Hikiba et al., 2005). Another set of in vitro studies assessing the potential of thymol to induce SCEs, CAs and micronuclei in HPBL were conducted using non-standard experimental parameters, including the use of longer incubation periods and testing only in the absence of metabolic activation. In the SCE, CA and micronucleus induction assays, HPBL were treated with thymol at concentrations of 25, 50, 75 and $100 \mu \mathrm{g} / \mathrm{mL}$ in 24 and $48 \mathrm{~h}$ experiments (Buyukleyla and Rencuzogullari, 2009). As stated above, the SCE assay was removed from the OECD library of standardized assays in 2014 (OECD, 2015) and its relevance to the safety evaluation cannot be assessed (Gooderham et al., 2020b). In the SCE and micronucleus induction assays, increases in SCE and micronuclei at all test concentrations in the $24 \mathrm{~h}$ and $48 \mathrm{~h}$ experiments were not concentration dependent. In the CA assay, a significant increase in CA was observed in the 24 and $48 \mathrm{~h}$ experiments but was not concentration-dependent in the $24 \mathrm{~h}$ experiment. A greater than 50\% decrease in the mitotic index was measured at $100 \mu \mathrm{g} / \mathrm{mL}$ thymol in both the $24 \mathrm{~h}$ and $48 \mathrm{~h}$ experiments, indicating significant cytotoxicity at this concentration (Buyukleyla and Rencuzogullari, 2009). In an OECD guideline-compliant in vitro CA assay, thymol was tested in Chinese hamster lung cells at 20,40 and 80 $\mu \mathrm{g} / \mathrm{mL}$ in the presence and absence of phenobarbital/5, 6-benzoflavone-induced rat liver S9 metabolic activation system. For the $6 \mathrm{~h}$ treatment in the presence of S9, thymol induced a statistically significant increase in the frequency of CA at $80 \mu \mathrm{g} / \mathrm{mL}$, at which $60 \%$ cytotoxicity was observed (JMHLW, 1996b; Kusakabe et al., 2002). However, it could not be concluded that the observed positive result was biologically relevant because a concentration-dependent trend was not demonstrated, and the apparent positive result was at concentrations at which excessive cytotoxicity was observed.

In an in vitro micronucleus assay, thymol was tested in mouse lymphoma L5178Y/TK ${ }^{ \pm}$cells at concentrations ranging from 16 to $250 \mu \mathrm{M}$ 
(Maisanaba et al., 2015b). In a 24 h exposure test in the absence of S9 metabolic activation system and a $4 \mathrm{~h}$ exposure test with $\mathrm{S} 9$ metabolic activation, thymol did not induce micronuclei formation at concentrations up to $250 \mu \mathrm{M}$. In OECD guideline-compliant in vitro micronucleus induction assays in HPBL, thymol did not induce micronuclei formation in binucleated cells (Roy and Jois, 2012b). Thymol was tested at concentrations of $15-70 \mu \mathrm{g} / \mathrm{mL}$ in $4 \mathrm{~h}$ treatments in the presence of an $\mathrm{S9}$ metabolic activation system derived from Aroclor 1254-induced rat liver, at concentrations of $15-85 \mu \mathrm{g} / \mathrm{mL}$ in $4 \mathrm{~h}$ treatments in the absence of S9 and at concentrations of $3.25-50 \mu \mathrm{g} / \mathrm{mL}$ in $24 \mathrm{~h}$ treatments in the absence of S9. Cytotoxicity, measured by CBPI, was significant at concentrations $\geq 150 \mu \mathrm{g} / \mathrm{mL}$ in all the $4 \mathrm{~h}$ treatments, with and without S9 and $>45 \mu \mathrm{g} / \mathrm{mL}$ in the $24 \mathrm{~h}$ treatment. There was no induction of micronuclei upon treatment with thymol in the three experiments.

Two OECD and GLP guideline-compliant in vivo micronucleus induction assays concluded that thymol was not genotoxic when administered to ICR or $\mathrm{BDF}_{1}$ mice by oral gavage (ECHA, 1995; JMHLW, 1996a). ICR mice were provided a single dose of 275 , 550 or 1100 $\mathrm{mg} / \mathrm{kg}$ bw, and $\mathrm{BDF}_{1}$ mice were provided a single dose of 312,625 or $1250 \mathrm{mg} / \mathrm{kg}$ bw. Treatment with thymol did not induce any statistically significant increases in micronucleated polychromatic erythrocytes of the femoral bone marrow in either in vivo study (ECHA, 1995; JMHLW, 1996c). Slight reductions in the ratio of polychromatic erythrocytes to total erythrocytes for high-dose animals in the study in ICR mice confirmed that the target tissue (bone marrow) had been reached (ECHA, 1995).

In a series of reverse mutation (Ames) assays and two forward mutation assays thymol was negative for mutagenicity. In an OECD guideline-compliant in vitro CA assay in Chinese hamster lung cells, thymol induced chromosomal aberrations, but only at the highest concentration, in the presence of metabolic activation, where significant cytotoxicity was also observed. Mixed results were reported for thymol in other non-standard in vitro CA assays but in two OECD guidelinecompliant in vitro micronucleus assays in human peripheral blood lymphocytes and mouse lymphoma L5178Y/TK ${ }^{ \pm}$, thymol did not increase the frequency of micronuclei. Two OECD guideline-compliant in vivo micronucleus assays reported no induction of micronuclei in the bone marrow of mice with the administration of thymol by oral gavage. Based on the weight of evidence of negative results for mutagenicity and genotoxicity in OECD guideline-compliant in vitro and in vivo assays, thymol is not of concern with respect to genotoxicity (Gooderham et al., 2020b).

7.1.2.2. Subchronic toxicity. A 19-week dietary toxicity study was conducted in which thymol was administered to Osborne-Mendel strain rats (5/sex/group) at concentrations of 0 (control), 1000 or $10,000 \mathrm{ppm}$ in the diet, corresponding to estimated intakes of 0,50 or $500 \mathrm{mg} / \mathrm{kg} \mathrm{bw} /$ day, respectively (FDA, 1993). At study termination, blood samples were collected for hematology, and the liver, kidneys, spleen, heart, testes and other organs and tissues, were examined macroscopically and microscopically. There were no adverse effects in hematological parameters or histopathology observed in any of the treatment groups, and the No-Observed-Adverse-Effect Level (NOAEL) was determined to be the highest dose tested of $500 \mathrm{mg} / \mathrm{kg}$ bw/day (Hagan et al., 1967).

7.1.2.3. Reproductive/developmental toxicity. In an OECD guidelinecompliant combined repeated dose and reproductive/development toxicity study, groups of male and female Sprague-Dawley rats were administered thymol at dose levels of 0 (control), 8,40 or $200 \mathrm{mg} / \mathrm{kg}$ bw/day by oral gavage. Male rats were administered thymol during the two-week pre-mating period, the two-week mating period and postmating for a total of 43 days; females were administered thymol throughout the pre-mating, mating and gestational periods through Lactation Day 4 for a total of 52 days. One male of the $200 \mathrm{mg} / \mathrm{kg}$ bw/ day dose group was found dead, but there were no deaths in any other treatment group. In the male high dose group, a decrease in body weight gain was reported. A transient decrease in locomotor activity and transient ataxia was reported in several female rats in the high dose group and was attributed to anesthetic action and muscle contraction suppression action of thymol. No changes were observed in hematological and blood chemistry parameters. Histopathological examinations conducted on mid- and/or high-dose males revealed increased incidences of slight to moderate squamous epithelial hyperplasia, slight inflammatory cell infiltration and slight edema in the forestomach when compared to the control group. Increased incidences of these forestomach findings attributed to gavage administration were also reported in mid- and highdose females: slight to moderate squamous epithelial hyperplasia and slight inflammatory cell infiltration. The forestomach findings were not considered toxicologically relevant due to the absence of these rodentspecific organs in humans (Maronpot et al., 2004; Proctor et al., 2007). In female rats, involution of the thymus was observed in one mid-dose and one-high-dose animal, and increased fat droplets in the zona fasciculata of the adrenal cortex were observed in one high-dose animal; both findings have been interpreted to be secondary stress responses due to pregnancy (Greaves, 1991; Pearse, 2006). Administration of thymol did not lead to adverse effects on reproductive or developmental parameters. Slightly lower body weights and decreased body weight gains were observed in F1 male and female rats at the high dose level but were attributed to higher litter size. Since the forestomach findings are not relevant to humans and the endocrine findings were related to stress, the FEMA Expert Panel determined a NOAEL of 200 $\mathrm{mg} / \mathrm{kg}$ bw/day for systemic toxicity. The NOAELs for reproductive and developmental toxicity were also determined to be $200 \mathrm{mg} / \mathrm{kg}$ bw/day (JMHLW, 1996a).

\subsubsection{Carvacrol methyl ether}

Genotoxicity. Carvacrol methyl ether was tested in a reverse mutation study conducted according to OECD and GLP guidelines in bacterial strains $S$. typhimurium TA98, TA100, TA1535 and TA1537 and E. coli WP2uvrA at a concentration range of 1.5-5000 $\mu \mathrm{g}$ /plate in the absence and presence of S9 metabolic activation derived from the livers of Aroclor 1254-treated rats. Carvacrol methyl ether was negative for mutagenic potential at concentrations up to $5000 \mu \mathrm{g} /$ plate (Dakoulas, 2016). Carvacrol methyl ether did not induce the formation of micronuclei in human peripheral blood lymphocytes incubated with and without Aroclor 1254-induced rat liver S9 metabolic activation when tested up to $200 \mu \mathrm{g} / \mathrm{mL}$ for the 4 -h treatments (with and without S9) and up to $60 \mu \mathrm{g} / \mathrm{mL}$ for the 24-h treatment period (without S9) in an OECD and GLP guideline-compliant in vitro micronucleus study (Roy, 2016).

\subsection{Natural flavor complexes}

For the NFCs under consideration, genotoxicity and the following sub-chronic toxicity studies are available.

\subsubsection{Origanum oil (extractive)}

Genotoxicity. Two strains of S. typhimurium, TA98 and TA102, were incubated with the alcohol extract of origanum (Thymus capitatus L.) in a reverse mutation assay. The origanum extract was mutagenic in strain TA98 and non-mutagenic in strain TA102 at a concentration of 10,000 $\mu \mathrm{g} /$ plate (Mahmoud et al., 1992). The authors concluded that the extract was positive in TA98 based on the number of colonies counted in the culture minus the number of spontaneous revertants. Fold increase, which is a commonly used method of assessing degree of mutagenicity, was not determined, nor was cytotoxicity evaluated. Therefore, the positive result was not considered relevant. In another experiment, the essential oil obtained by steam distillation of origanum, containing $53 \%$ carvacrol, 16\% thymol, 7\% linalool, 5\% p-cymene, 4\% $p$-mentha-1, 
4-diene with other reported minor constituents and consistent with the composition of Origanum Oil FEMA 2828, was assessed for its genotoxic potential in the rec and Ames assays (Zani et al., 1991). The rec assay was negative at concentrations of 10 and $30 \mu \mathrm{L} /$ disk but the relevance of this assay is unclear. The OECD notes that indicator tests such as the rec assay should be considered with the results of other assays that measure DNA damage or mutagenicity that can be passed on to subsequent generations (OECD, 2015). In the reverse mutation assay, mutagenic activity was not detected in $S$. typhimurium strains TA98, TA100, TA1535 and TA1537 at concentrations up to $300 \mu \mathrm{g}$ /plate origanum oil in both the presence and absence of Aroclor-induced rat liver S9 (Zani et al., 1991).

\subsubsection{Related NFC: Oregano (Origanum vulgare) essential oil}

7.2.2.1. Genotoxicity. In an OECD guideline-compliant combined micronucleus induction and comet assay, groups of male and female Wistar rats (5/sex/dose) were administered 50,100 or $200 \mathrm{mg} / \mathrm{kg}$ bw per day of oregano oil for 90 days. (Llana-Ruiz-Cabello et al., 2018). The composition of the test substance, determined by GC-MS analysis, was $56 \%$ carvacrol, $5 \%$ thymol, $15 \% p$-cymene, $4 \% \gamma$-terpinene with other minor terpenoid constituents. At the end of the study, the animals were terminated and the femoral bone marrow was isolated, fixed and stained for analysis. Peripheral blood lymphocytes and stomach (portion not specified) and liver samples were collected and subjected to standard and enzyme modified comet analyses. There was no increased frequency of micronucleus induction in the bone marrow of rats administered oregano oil under the conditions of this study. In the comet assays, both standard and Endo III/FPG assays, there were no increased occurrences of DNA strand breaks detected in the tissues analyzed.

7.2.2.2. Subchronic toxicity. In a 90 day repeated dose study performed in accordance to the OECD Guideline 408, oregano oil derived from Origanum vulgare was administered to $\mathrm{Crl}: \mathrm{W} 1(\mathrm{Han})$ (type outbred) Wistar rats (10/sex/group) in the diet (Llana-Ruiz-Cabello et al., 2017). The composition of the test substance, determined by GC-MS analysis, was $56 \%$ carvacrol, $5 \%$ thymol, $15 \%$ p-cymene, $4 \% \gamma$-terpinene with other minor terpenoid constituents. The levels of oregano oil administered were 0 (neutral gelatine), 1000,2000 or $4000 \mathrm{mg} / \mathrm{kg}$ feed providing a dose of $0,50,100$ or $200 \mathrm{mg} / \mathrm{kg}$ bw per day of oregano oil, respectively. Animals were observed daily and body weights, food and water consumption measurements were recorded weekly. Blood samples were collected for hematology and clinical chemistry analyses. At termination, gross necropsies were conducted on all animals and major tissues and organs were collected, weighed and preserved. All high-dose and vehicle control animals were subject to detailed necropsy and histopathology of the liver, kidney, intestine, stomach, lung, heart, and testicle or ovary.

There were no mortalities and no abnormal clinical observations during the study period. Body weight gain, food and water consumption were comparable across control and test groups throughout the study. Clinical biochemistry and hematology analyses showed a statistically significant decrease in serum glucose in the $50 \mathrm{mg} / \mathrm{kg}$ bw per day males, a statistically significant increase in serum glucose in the $200 \mathrm{mg} / \mathrm{kg}$ bw per day females and a statistically significant decrease in red cell distribution width for the $200 \mathrm{mg} / \mathrm{kg}$ bw per day female group. Gross necropsy revealed no changes in organ weights in the treated groups compared to the control group except for a slight increase in kidney weight for the $200 \mathrm{mg} / \mathrm{kg}$ bw per day females when compared to the $100 \mathrm{mg} / \mathrm{kg}$ bw per day female group and a significant increase in the ovary weights for the $50 \mathrm{mg} / \mathrm{kg}$ bw per day females. Histopathological analyses of the liver, kidney, intestine, stomach, lung, heart, and testicle or ovary found no differences between the control and treatment groups. The study authors determined a NOAEL of $200 \mathrm{mg} / \mathrm{kg}$ bw per day oregano oil in rats.

\subsubsection{Savory summer oil}

Genotoxicity. The essential oil of Satureja hortensis (38\% p-mentha-1,4diene, $37 \%$ carvacrol, $8 \%$-cymene, $3 \% 3$-carene, $2 \%$ myrcene, $2 \%$ $\beta$-caryophyllene, $1 \% \alpha$-pinene and other reported minor constituents) was not mutagenic at concentrations up to $300 \mu \mathrm{g} /$ plate in an Ames study in S. typhimurium strains TA98, TA100, TA1535 and TA1537 in the presence and absence of $S 9$ derived from the livers of Aroclor-treated rats (Zani et al., 1991). Savory summer oil was also tested in a rec assay at 10 or $30 \mu \mathrm{L} /$ disk. Savory summer oil was negative in this assay, but the relevance of this indicator assay for genotoxicity and repair is unclear. The OECD notes that indicator tests such as the rec assay should be considered with the results of other assays that measure DNA damage or mutagenicity that can be passed on to subsequent generations (OECD, 2015).

\subsubsection{Savory winter oil}

Genotoxicity. Savory winter oil, composed of $36 \%$ carvacrol, $27 \% p$ cymene, $7 \% p$-mentha-1,4-diene, $4 \%$ humulene, $2 \%$ thymol with other minor constituents, was tested in two in vitro mutagenicity assays. In a rec assay, $S$. montana was tested at 10 or $30 \mu \mathrm{L} /$ disk and did not induce bacterial growth inhibition. As discussed previously, the relevance of this assay is unclear (OECD, 2015). A reverse mutation assay tested the same oil in four $S$. typhimurium strains in the presence and absence of an S9 metabolic activation system derived from Aroclor-induced rat liver. Savory winter oil did not cause any increases in revertant colony numbers in TA98, TA100, TA1535 or TA1537 (Zani et al., 1991).

\subsubsection{Savory oil (unspecified type)}

Genotoxicity. An essential oil of savory was tested in S. typhimurium strains TA98, TA100, TA1535, TA1537 and TA1538 up to concentrations of $0.1 \mu \mathrm{g} /$ plate in the presence and absence of phenobarbital/5,6benzoflavone-treated rat liver $S 9$ in a reverse mutation assay. Savory oil did not increase the frequency of revertant colonies under any of the tested conditions and was concluded to be non-mutagenic (Ishidate et al., 1988). Two independent reverse mutation assays in S. typhimurium strains TA98 and TA100 tested an ethanolic savory extract (Namiki et al., 1984). The ethanolic extract was found to be negative when tested at 10,30 or $50 \mathrm{mg} /$ plate in the presence and absence of $\mathrm{S} 9$ metabolic activation (Namiki et al., 1984).

Savory oil was positive in a rec assay in experiments both with and without S9 metabolic activation at 4 and $1.5 \mathrm{mg} /$ disk, respectively (Ishidate et al., 1988). No current testing guidelines are available for the rec assay; additionally, the OECD notes that the results of indicator tests, including the rec assay, should be evaluated with the results of other genotoxicity or mutagenicity assays (OECD, 2015). In a chromosome aberration study, Chinese hamster lung cells were incubated with savory oil at a single concentration of $0.1 \mathrm{mg} / \mathrm{mL}$. After a 24-h incubation in the presence of Kanechlor 400-induced rat liver S9, the frequency of structural aberrations increased whereas in the absence of S9, savory oil did not induce chromosomal aberrations after 24- and 48-h treatment. Cytotoxicity of the test substance in Chinese hamster lung cells was not reported (Ishidate et al., 1988).

\subsubsection{Thyme oil}

7.2.6.1. Genotoxicity. Essential oils from two variants of Thymus vulgaris L. were analyzed for their mutagenic potential in S. typhimurium strains TA98, TA100, TA1535 and TA1537. The first essential oil had a composition of $44 \%$ p-cymene, $23 \%$ thymol, $5 \%$ p-mentha-1,4-diene, $3 \%$ eucalyptol and other minor constituents; the second essential oil contained 34\% thymol, 25\% p-cymene, 10\% p-mentha-1,4-diene, $4 \%$ linalool, $4 \%$ caryophyllene and other minor constituents. Both essential 
oils were non-mutagenic when tested with and without S9 metabolic activation system from Aroclor-induced rat liver up to $1000 \mu \mathrm{g} /$ plate (Zani et al., 1991). Several screening assays have also been conducted on thyme oil or extract in S. typhimurium TA98 and/or TA100 in the presence or absence of $S 9$ activation up to an overall maximum concentration of $50 \mathrm{mg} /$ plate, and all concluded that the test substance was not mutagenic under the conditions tested (De Martino et al., 2009; Namiki et al., 1984; Shoeibi et al., 2009).

A reverse mutation assay using $S$. typhimurium strains TA98, TA1535, TA1537 and TA1538 concluded that thyme oil was weakly mutagenic at a concentration of $5 \mathrm{ng} /$ plate in TA98 and TA1538 and mutagenic at 5 $\mathrm{ng} /$ plate in TA1537, but non-mutagenic up to $10 \mathrm{ng} /$ plate in TA1537 (Sivaswamy et al., 1991). As discussed previously (Rietjens et al., 2020), the authors of this study did not indicate whether there was a concentration-dependent response, did not evaluate test substance toxicity and tested concentrations that are unusually low and the quality of the study presented does not meet current widely-accepted test guidelines (OECD, 1997).

A rec assay conducted on thyme oil resulted in a positive result when the substance was tested in the absence of metabolic activation, but a negative result was obtained in the presence of Aroclor 1254-induced liver S9 activation (Ueno et al., 1984). As noted above, the rec assay is an indicator test that should be considered with the results of other assays that measure DNA damage or mutagenicity that can be passed on to subsequent generations (OECD, 2015).

An in vitro chromosome aberration assay tested thyme oil at three concentrations up to $50 \mu \mathrm{g} / \mathrm{plate}$, which did not induce cytotoxicity. After a 48-h treatment period in the presence and absence of Kanechlor KC 400-induced rat liver S9, thyme oil did not cause any numerical or structural aberrations in Chinese hamster fibroblasts, and it was concluded to be non-genotoxic (Ishidate et al., 1984). A commercial sample of thyme oil was assessed in an in vitro comet assay in human embryo lung 12,469 cells. When tested at concentrations of 0.0025 , $0.005,0.01,0.025$ and $0.05 \mu \mathrm{L} / \mathrm{mL}$, thyme oil did not increase the $\%$ tail DNA in treated cells. Therefore, thyme oil was concluded to be negative for the induction of DNA damage (Puskarova et al., 2017). Due to the lack of a standardized procedure for the performance and evaluation of results of the in vitro comet assay, the relevance of this result cannot be assessed (Gooderham et al., 2020b).

Thyme oil did not show mutagenicity in the Ames assay and was negative for genotoxicity in a chromosomal aberration assay in Chinese hamster fibroblasts. The weight of evidence of these studies indicates no genotoxic concern for thyme oil.

7.2.6.2. Subchronic toxicity. Thyme oil was evaluated for toxicity in a 28-day repeat oral dose study conducted in accordance with OECD testing guidelines with slight modifications. Thyme oil was analyzed and shown to contain $46 \%$ thymol, $20 \%$ p-mentha-1,4-diene, $16 \%$ p-cymene, $3 \% p$-menth-1,3-diene, $2 \% \beta$-myrcene and other minor compounds (Rojas-Armas et al., 2019). Groups of 5 male and 5 female Holtzman strain rats were orally administered thyme oil at dose levels of 100, 250 or $500 \mathrm{mg} / \mathrm{kg} \mathrm{bw} /$ day. Animals were monitored twice daily for signs of toxicity and mortality. Body weights were measured at study initiation and weekly thereafter. On the day of necropsy, blood samples were collected for hematological and clinical chemistry assessments. At study termination, all animals were necropsied, and organs and tissues were excised, weighed and fixed for histopathological examinations. During the study period, there were no deaths or signs of toxicity. Mean group body weights of females were comparable between treated and control groups. For high-dose males, statistically significant lower mean body weights were reported compared to the control group ( $<<0.05)$. The study authors did not correlate this reduction in body weight with reduced food consumption. The reduced body weights in the high dose male group were not accompanied by changes in the relative weights of the organs. There were no statistically significant changes in hematology and clinical chemistry parameters in male and female animals administered thyme oil. Relative organ weights for both male and female treatment groups were comparable to the control groups. Histopathological findings included mild inflammatory infiltrates in the liver (70\%) at all dose levels, although this is a common finding even in control rats; moderate inflammatory infiltrates of the lungs (65\%) in low- and mid-dose animals were more severe in high dose animals where hemorrhagic foci were also observed. The changes in the lung were irritative in nature and may have arisen as a consequence of partial exhalation of the volatile test substance administered by gavage. Mild acute inflammation in the stomach was observed in one mid-dose animal and two high-dose animals (sex not reported). In the esophagus, a moderate sub-epithelial inflammatory cell infiltrate was observed in one high-dose animal (sex not reported). The study authors attributed the findings in the stomach and esophagus to be due to gavage administration of the thymol oil. Based on these findings, the study authors determined the NOAEL to be greater than $250 \mathrm{mg} / \mathrm{kg}$ bw/day in male and female rats (Rojas-Armas et al., 2019). Based on the authors description of the histopathological findings in the lung tissues described by the study authors, the FEMA Expert Panel determined a more conservative NOAEL of $100 \mathrm{mg} / \mathrm{kg} \mathrm{bw} /$ day that is possibly higher if the inflammatory infiltrates observed in the lungs are due to irritation caused by inhalation of the test substance. Based on a NOAEL of $100 \mathrm{mg} / \mathrm{kg}$ bw/day, the MoS for Thyme Oil (FEMA 3064) is greater than 27,000 and the MoS for Thyme White Oil (FEMA 3065) is greater than 2,000,000.

\subsubsection{Summary of NFC studies}

A review of available in vitro genotoxicity assays for origanum oil, savory (summer and winter) oil and thyme oil indicate a lack of genotoxic potential. These observations are consistent with the lack of genotoxic potential observed for carvacrol and thymol, major constituents of these essential oils. A short-term toxicity study of thyme oil presents sufficient margins of safety for Thyme Oil (FEMA 3064) and Thyme White Oil (FEMA 3065).

\section{Recognition of GRAS status}

The safety evaluation procedure of the FEMA Expert Panel was applied to the NFCs listed in Table 5, which were concluded to not present a safety concern. For Thyme Oil (FEMA 3064), Thyme White Oil (FEMA 3065), Savory Summer Oil (FEMA 3013), Savory Summer Oleoresin (FEMA 3014), Savory Winter Oil (FEMA 3016), Savory Winter Oleoresin (FEMA 3017) and Origanum Oil (Extractive) (FEMA 2828), the estimated intakes for their constituent congeneric groups are below the TTC for their respective structural classes, indicating no safety concern. Available genotoxicity studies for both the NFCs and their Group 20 (Phenol derivatives) constituents were reviewed and support the conclusion that these flavoring ingredients do not raise a concern for genotoxicity. Based on the safety evaluation described in this manuscript, these data support the affirmation of the generally recognized as safe (GRAS) status of the NFCs at the currently levels of intended use as flavoring ingredients.

Table 5

NFCs affirmed FEMA GRAS.

\begin{tabular}{ll}
\hline $\begin{array}{l}\text { FEMA } \\
\text { No. }\end{array}$ & Name \\
\hline 2828 & $\begin{array}{l}\text { Origanum Oil (Extractive) Thymus capitatus Hoffm. Et Link (syn. } \\
\text { Coridothymus capitatus Reich b.)] }\end{array}$ \\
3013 & Savory Summer Oil (Satureja hortensis L.) \\
3014 & Savory Summer Oleoresin (Satureja hortensis L.) \\
3016 & Savory Winter Oil (Satureja montana L.) \\
3017 & Savory Winter Oleoresin (Satureja montana L.) \\
3064 & Thyme Oil (Thymus vulgaris L., T. zygis) \\
3065 & Thyme White Oil (Thymus vulgaris L., T. zygis) \\
\hline
\end{tabular}




\section{CRediT authorship contribution statement}

Samuel M. Cohen: Conceptualization, Methodology, Formal analysis, Writing - original draft, Writing - review \& editing, Supervision, Conceptualization, Methodology, Formal analysis, Writing - original draft, Writing - review \& editing, Supervision. Gerhard Eisenbrand: Conceptualization, Methodology, Formal analysis, Writing - original draft, Writing - review \& editing, Supervision, Conceptualization, Methodology, Formal analysis, Writing - original draft, Writing - review \& editing, Supervision. Shoji Fukushima: Conceptualization, Methodology, Formal analysis, Writing - original draft, Writing - review \& editing, Supervision, Conceptualization, Methodology, Formal analysis, Writing - original draft, Writing - review \& editing, Supervision. Nigel J. Gooderham: Conceptualization, Methodology, Formal analysis, Writing - original draft, Writing - review \& editing, Supervision, Conceptualization, Methodology, Formal analysis, Writing - original draft, Writing review \& editing, Supervision. F. Peter Guengerich: Conceptualization, Methodology, Formal analysis, Writing - original draft, Writing - review \& editing, Supervision, Conceptualization, Methodology, Formal analysis, Writing - original draft, Writing - review \& editing, Supervision. Stephen S. Hecht: Conceptualization, Methodology, Formal analysis, Writing - original draft, Writing - review \& editing, Supervision, Conceptualization, Methodology, Formal analysis, Writing - original draft, Writing - review \& editing, Supervision. Ivonne M.C.M. Rietjens: Conceptualization, Methodology, Formal analysis, Writing - original draft, Writing - review \& editing, Supervision, Conceptualization, Methodology, Formal analysis, Writing - original draft, Writing - review \& editing, Supervision. Thomas J. Rosol: Conceptualization, Methodology, Formal analysis, Writing - original draft, Writing - review \& editing, Supervision, Conceptualization, Methodology, Formal analysis, Writing - original draft, Writing - review \& editing, Supervision. Jeanne M. Davidsen: Conceptualization, Methodology, Formal analysis, Investigation, Data curation, Visualization, Writing - original draft, Writing review \& editing, Supervision. Christie L. Harman: Conceptualization, Methodology, Formal analysis, Investigation, Data curation, Visualization, Writing - original draft, Writing - review \& editing, Supervision, Project administration, Funding acquisition. Vivian Lu: Data curation, Writing - original draft. Sean V. Taylor: Conceptualization, Methodology, Formal analysis, Investigation, Data curation, Visualization, Writing - original draft, Writing - review \& editing, Supervision, Project administration, Funding acquisition.

\section{Declaration of competing interest}

Drs. Cohen, Eisenbrand, Fukushima, Gooderham, Guengerich, Hecht, Rietjens and Rosol are members of the Expert Panel of the Flavor and Extract Manufacturers Association. Authors Davidsen, Harman, Lu and Taylor are employed by Verto Solutions, which provides scientific and management support services to FEMA. A full description of the conflict of interest protections and procedures used to ensure that the FEMA Expert Panel decisions are fully objective and based solely on the merits of the available information have been published (Marnett et al., 2013) and are available on the FEMA website at https://www. femaflavor.org/gras\# conflict.

\section{Acknowledgements}

This work was financially supported by the International Organization of the Flavor Industry (IOFI), the Flavor and Extract Manufacturers Association (FEMA) and the International Federation of Essential Oils and Aroma Trades (IFEAT).

\section{Appendix A. Supplementary data}

Supplementary data to this article can be found online at https://doi. org/10.1016/j.fct.2021.112378.

\section{References}

Adams, T., Hallagan, J., Putnam, J., Gierke, T., Doull, J., Munro, I., Newberne, P., Portoghese, P., Smith, R., Wagner, B., 1996. The FEMA GRAS assessment of alicyclic substances used as flavour ingredients. Food Chem. Toxicol. 34, 763-828.

Adams, T.B., Cohen, S.M., Doull, J., Feron, V.J., Goodman, J.I., Marnett, L.J., Munro, I. C., Portoghese, P.S., Smith, R.L., Waddell, W.J., Wagner, B.M., 2004. The FEMA GRAS assessment of cinnamyl derivatives used as flavor ingredients. Food Chem. Toxicol. 42, 157-185. https://doi.org/10.1016/j.fct.2003.08.021.

Adams, T.B., Cohen, S.M., Doull, J., Feron, V.J., Goodman, J.I., Marnett, L.J., Munro, I. C., Portoghese, P.S., Smith, R.L., Waddell, W.J., Wagner, B.M., 2005a. The FEMA GRAS assessment of benzyl derivatives used as flavor ingredients. Food Chem. Toxicol. 43, 1207-1240. https://doi.org/10.1016/j.fct.2004.11.014.

Adams, T.B., Cohen, S.M., Doull, J., Feron, V.J., Goodman, J.I., Marnett, L.J., Munro, I. C., Portoghese, P.S., Smith, R.L., Waddell, W.J., Wagner, B.M., 2005b. The FEMA GRAS assessment of hydroxy- and alkoxy-substituted benzyl derivatives used as flavor ingredients. Food Chem. Toxicol. 43, 1241-1271. https://doi.org/10.1016/j. fct.2004.12.018.

Adams, T.B., Cohen, S.M., Doull, J., Feron, V.J., Goodman, J.I., Marnett, L.J., Munro, I. C., Portoghese, P.S., Smith, R.L., Waddell, W.J., Wagner, B.M., 2005c. The FEMA GRAS assessment of phenethyl alcohol, aldehyde, acid, and related acetals and esters used as flavor ingredients. Food Chem. Toxicol. 43, 1179-1206. https://doi.org/ 10.1016/j.fct.2004.11.013.

Adams, T.B., Doull, J., Feron, V.J., Goodman, J.I., Marnett, L.J., Munro, I.C., Newberne, P.M., Portoghese, P.S., Smith, R.L., Waddell, W.J., Wagner, B.M., 2002. The FEMA GRAS assessment of pyrazine derivatives used as flavor ingredients. Food Chem. Toxicol. 40, 429-451. https://doi.org/10.1016/s0278-6915(01)00123-5.

Adams, T.B., Doull, J., Goodman, J.I., Munro, I.C., Newberne, P., Portoghese, P.S., Smith, R.L., Wagner, B.M., Weil, C.S., Woods, L.A., Ford, R.A., 1997. The FEMA GRAS assessment of furfural used as a flavour ingredient. Food Chem. Toxicol. 35, 739-751. https://doi.org/10.1016/s0278-6915(97)00056-2.

Adams, T.B., Gavin, C.L., McGowen, M.M., Waddell, W.J., Cohen, S.M., Feron, V.J., Marnett, L.J., Munro, I.C., Portoghese, P.S., Rietjens, I.M.C.M., Smith, R.L., 2011. The FEMA GRAS assessment of aliphatic and aromatic terpene hydrocarbons used as flavor ingredients. Food Chem. Toxicol. 49, 2471-2494. https://doi.org/10.1016/j. fct.2011.06.011.

Adams, T.B., Gavin, C.L., Taylor, S.V., Waddell, W.J., Cohen, S.M., Feron, V.J., Goodman, J., Rietjens, I.M.C.M., Marnett, L.J., Portoghese, P.S., Smith, R.L., 2008. The FEMA GRAS assessment of alpha,beta-unsaturated aldehydes and related substances used as flavor ingredients. Food Chem. Toxicol. 46, 2935-2967. https:// doi.org/10.1016/j.fet.2008.06.082.

Adams, T.B., Greer, D.B., Doull, J., Munro, I.C., Newberne, P., Portoghese, P.S., Smith, R. L., Wagner, B.M., Weil, C.S., Woods, L.A., Ford, R.A., 1998. The FEMA GRAS assessment of lactones used as flavour ingredients. Food Chem. Toxicol. 36, 249-278. https://doi.org/10.1016/s0278-6915(97)00163-4.

Adams, T.B., McGowen, M.M., Williams, M.C., Cohen, S.M., Feron, V.J., Goodman, J.I., Marnett, L.J., Munro, I.C., Portoghese, P.S., Smith, R.L., Waddell, W.J., 2007. The FEMA GRAS assessment of aromatic substituted secondary alcohols, ketones, and related esters used as flavor ingredients. Food Chem. Toxicol. 45, 171-201. https:// doi.org/10.1016/j.fct.2006.07.029.

Arctander, S., 1961. Perfume and Flavor Materials of Natural Origin. Allured Publishing Corporation, Carol Stream, IL, USA.

Aydin, S., Basaran, A.A., Basaran, N., 2005a. The effects of thyme volatiles on the induction of DNA damage by the heterocyclic amine IQ and mitomycin C. Mutation research 581, 43-53. https://doi.org/10.1016/j.mrgentox.2004.10.017.

Aydin, S., Basaran, A.A., Basaran, N., 2005b. Modulating effects of thyme and its major ingredients on oxidative DNA damage in human lymphocytes. J. Agric. Food Chem. 53, 1299-1305.

Azizan, A., Blevins, R.D., 1995. Mutagenicity and antimutagenicity testing of six chemicals associated with the pungent properties of specific spices as revealed by the Ames Salmonella/microsomal assay. Arch. Environ. Contam. Toxicol. 28 https://doi. org/10.1007/bf00217624.

Bhalli, J., 2014. 2-Methyl-5-(1-Methylethyl)-Phenol (CAS No. 499-75-2): Bacterial Reverse Mutation Assay: Plate Incorporation Method with a Confirmatory Assay, Unpublished Study Report, Study No. 8289031. Covance Laboratories, Greenfield, pp. 1-63.

Buyukleyla, M., Rencuzogullari, E., 2009. The effects of thymol on sister chromatid exchange, chromosome aberration and micronucleus in human lymphocytes. Ecotoxicol. Environ. Saf. 72, 943-947.

Charles, D.J., 2013. Antioxidant Properties of Spices, Herbs and Other Sources. Springer, New York, NY.

Cohen, S.M., Eisenbrand, G., Fukushima, S., Gooderham, N.J., Guengerich, F.P., Hecht, S. S., Rietjens, I.M.C.M., Bastaki, M., Davidsen, J.M., Harman, C.L., McGowen, M.M., Taylor, S.V., 2020. FEMA GRAS assessment of natural flavor complexes: mint, buchu, dill and caraway derived flavoring ingredients. Food Chem. Toxicol. : an international journal published for the British Industrial Biological Research Association 135, 110870. https://doi.org/10.1016/j.fct.2019.110870.

Cohen, S.M., Eisenbrand, G., Fukushima, S., Gooderham, N.J., Guengerich, F.P., Hecht, S. S., Rietjens, I.M.C.M., Davidsen, J.M., Harman, C.L., Taylor, S.V., 2018. Updated procedure for the safety evaluation of natural flavor complexes used as ingredients in food. Food Chem. Toxicol. 113, 171-178. https://doi.org/10.1016/j. fct.2018.01.021.

Cohen, S.M., Eisenbrand, G., Fukushima, S., Gooderham, N.J., Guengerich, F.P., Hecht, S. S., Rietjens, I.M.C.M., Bastaki, M., Davidsen, J.M., Harman, C.L., McGowen, M. Taylor, S.V., 2019. FEMA GRAS assessment of natural flavor complexes: Citrus- 
derived flavoring ingredients. Food Chem. Toxicol. 124, 192-218. https://doi.org/ 10.1016/j.fct.2018.11.052

Cramer, G.M., Ford, R.A., Hall, R.L., 1978. Estimation of toxic hazard-a decision tree approach. Food Chem. Toxicol. 16, 255-276.

Dakoulas, E., 2016. 4-Isopropyl-2-methoxy-1-methylbenzene (CAS\# 6379-73-3): Bacterial Reverse Mutation Assay, Unpublished Study Report, Study No. AE21NN.503. BTL. BioReliance Corporation, Rockville, MD, pp. 1-53.

De Martino, L., De Feo, V., Nazzaro, F., 2009. Chemical composition and in vitro antimicrobial and mutagenic activities of seven Lamiaceae essential oils. Molecules $14,4213-4230$

ECHA, 1989. Thymol. In vitro gene mutation study in bacteria. REACH registration dossiers. European Chemicals Agency. (Accessed 15 March 2021).

ECHA, 1995. Thymol. Genetic toxicity: in vivo mammalian germ cell study: gene mutation. REACH registration dossiers. European Chemicals Agency. (Accessed 15 March 2021).

ECHA, 2010. Thymol. In vitro gene mutation study in mammalian cells. REACH registration dossiers. European Chemicals Agency. (Accessed 15 March 2021).

EFSA, 2016. Review of the Threshold of Toxicological Concern (TTC) approach and development of new TTC decision tree. EFSA Supporting Publications 13, 1-50. https://doi.org/10.2903/sp.efsa.2016.EN-1006.

Eisenbrand, G., Cohen, S.M., Fukushima, S., Gooderham, N.J., Guengerich, F.P., Hecht, S. S., Rietjens, I.M.C.M., Davidsen, J.M., Harman, C.L., Taylor, S.V., 2021. FEMA GRAS Assessment of Natural Flavor Complexes: Eucalyptus Oil and Other Cyclic Ether Containing Flavoring Ingredients. Food and Chemical Toxicology, doi:10.1016/j. fct.2021.112357. In press.

ERS/USDA, 2020. http://www.ers.usda.gov/data-products/food-availability-(per-capita )-data-system/food-availability-documentation.aspx..Economic Research Service, United States Department of Agriculture.

FDA, 1993. Priority-Based Assessment of Food Additives (PAFA). United States Food and Drug Administration Center for Food Safety and Applied Nutrition, College Park, MD, p. 58.

Florin, I., Rutberg, L., Curvall, M., Enzell, C.R., 1980. Screening of tobacco smoke constituents for mutagenicity using the ames test. Toxicology 15, 219-232. https:// doi.org/10.1016/0300-483x(80)90055-4.

Food Chemical Codex, 2020. Spice Oleoresins, 12th ed. United States Pharmacopeia (USP), Rockville, MD, USA.

Fukuda, S., 1987. Assessment of the carcinogenic hazard of 6 substances used in dental practices. I. Morphological transformations, DNA damage and SCE in cultured Syrian hamster embryo cells induced by camphor, eugenol, thymol, EDTA, benzalkonium chloride and benzethonium chloride. Shigaku 74, 1365-1384.

Fukushima, S., Cohen, S.M., Eisenbrand, G., Gooderham, N.J., Guengerich, F.P., Hecht, S. S., Rietjens, I.M.C.M., Rosol, T.J., Davidsen, J.M., Harman, C.L., Lu, V., Taylor, S.V., 2020. FEMA GRAS assessment of natural flavor complexes: lavender, Guaiac Coriander-derived and related flavoring ingredients. Food Chem. Toxicol. 111584 https://doi.org/10.1016/j.fct.2020.111584.

Gooderham, N.J., Cohen, S.M., Eisenbrand, G., Fukushima, S., Guengerich, F.P., Hecht, S S., Rietjens, I.M.C.M, Rosol, T.J., Davidsen, J.M., Harman, C.L., Murray, I.J., Taylor, S.V., 2020a. FEMA GRAS assessment of natural flavor complexes: clove, Cinnamon leaf and West Indian bay leaf-derived flavoring ingredients. Food Chem. Toxicol. 111585 https://doi.org/10.1016/j.fct.2020.111585.

Gavin, C., Williams, M., Hallagan, J., 2008. 2005 Poundage and Technical Effects Survey. Flavor and Extract Manufacturers Association of the United States (FEMA), Washington, D.C., USA.

Gooderham, N.J., Cohen, S.M., Eisenbrand, G., Fukushima, S., Guengerich, F.P., Hecht, S. S., Rietjens, I.M.C.M., Rosol, T.J., Bastaki, M., Linman, M.J., Taylor, S.V., 2020b. The safety evaluation of food flavoring substances: the role of genotoxicity studies. Current Reviews in Toxicology. https://doi.org/10.1080/10408444.2020.1712589.

Greaves, P., 1991. Histopathology of Preclinical Toxicity Studies: Interpretation and Relevance in Drug Safety Evaluation, 1 ed. Elsevier, Amsterdam, the Netherlands.

Grieve, M., 1970. A Modern Herbal: the Medicinal, Culinary, Cosmetic and Economic Properties, Cultivation and Folk-Lore of Herbs, Grasses, Fungi, Shrubs, and Trees with All Their Modern Scientific Uses, II. Hafner Publishing Co., Darien, CT.

Hagan, E.C., Hansen, W.H., Fitzhugh, O.G., Jenner, P.M., Jones, W.I., Taylor, J.M., Long, E.L., Nelson, A.A., Brouwer, J.B., 1967. Food flavourings and compounds of related structure. II. Subacute and chronic toxicity. Food Chem. Toxicol. 5, 141-157. https://doi.org/10.1016/s0015-6264(67)82961-4.

Hallagan, J.B., Hall, R.L., 1995. FEMA GRAS - a GRAS assessment program for flavor ingredients. Regul. Toxicol. Pharmacol. 21, 422-430. https://doi.org/10.1006/ rtph.1995.1057.

Hallagan, J.B., Hall, R.L., 2009. Under the conditions of intended use - new developments in the FEMA GRAS program and the safety assessment of flavor ingredients. Food Chem. Toxicol. 47, 267-278. https://doi.org/10.1016/j. fct.2008.11.011.

Hallagan, J.B., Hall, R.L., Drake, J., 2020. The GRAS provision - the FEMA GRAS program and the safety and regulation of flavors in the United States. Food Chem. Toxicol. 138, 111236. https://doi.org/10.1016/j.fct.2020.111236.

Harman, C.L., Drake, J., Murray, I.J., 2018. 2015 Poundage and Technical Effects Survey. Flavor and Extract Manufacturers Association of the United States (FEMA), Washington. DC, USA.

Harman, C.L., Lipman, M.D., Hallagan, J.B., 2013. 2010 Poundage and Technical Effects Survey. Flavor and Extract Manufacturers Association, Washington, DC, USA.

Hikiba, H., Watanabe, E., Barrett, J.C., Tsutsui, T., 2005. Ability of fourteen chemical agents used in dental practice to induce chromosome aberrations in Syrian hamster embryo cells. J Pharmcol Sci 97, 146-152.
Horvathova, E., Turcaniova, V., Slamenova, D., 2007. Comparative study of DNAdamaging and DNA-protective effects of selected components of essential plant oils in human leukemic cells K562. Neoplasma 54, 478-483.

Ipek, E., Tuylu, B.A., Zeytinoglu, H., 2003. Effects of carvacrol on sister chromatid exchanges in human lymphocyte cultures. Cytotechnology 43, 145-148.

Ipek, E., Zeytinoglu, H., Okay, S., Tuylu, B.A., Kurkcuoglu, M., Baser, K.H., 2005. Genotoxicity and antigenotoxicity of Origanum oil and carvacrol evaluated by Ames Salmonella/microsomal test. Food Chem. 93, 551-556.

Ishidate, M., Sofuni, T., Yoshikawa, K., Hayashi, M., Nohmi, T., Sawada, M., Matsuoka, A., 1984. Primary mutagenicity screening of food additives currently used in Japan. Food Chem. Toxicol. 22, 623-636.

Ishidate, M., Takizawa, Y., Sakabe, Y., Ishizaki, M., Watanbe, M., Tachi, M., Takemoto, K., 1988. Mutagenicity test of food additives (Part 9) (supported by the ministry of Health and welfare Research grant). Toxicology Forum 11, 663-669.

JMHLW, 1996a. Combined Repeat Dose and Reproductive/developmental Toxicity Screening Test of Thymol by Oral Administration in Rats, Unpublished Study Report. Japan Ministry of Health, Labour and Welfare. Study no. 4L421KEO.

JMHLW, 1996b. In Vitro Chromosomal Aberration Test of Thymol on Cultured Chinese Hamster Cells, Unpublished Study Report. Japan Ministry of Health, Labour and Welfare.

JMHLW, 1996c. Micronucleus Test of Thymol on Mice, Unpublished Study Report. Japan Ministry of Health, Labour and Welfare.

JMHLW, 1996d. Reverse Mutation Testing of Thymol on Bacteria, Unpublished Study Report. Japan Ministry of Health, Labour and Welfare.

Kono, M.Y.Y., Itaya, Y., Shimobo, K., Yoshikawa, K., Terashita, T., Shishiyama, J., 1995. Antimicrobial activity and mutagenicity of allyl isothiocyanate and several essential oils from spices. Mem. Fac. Agric. Kinki Univ. 28, 11-19.

Koster, S., Boobis, A.R., Cubberley, R., Hollnagel, H.M., Richling, E., Wildemann, T., Wurtzen, G., Galli, C.L., 2011. Application of the TTC concept to unknown substances found in analysis of foods. Food Chem. Toxicol. 49, 1643-1660. https:// doi.org/10.1016/j.fct.2011.03.049.

Kroes, R., Galli, C., Munro, I., Schilter, B., Tran, L., Walker, R., Wurtzen, G., 2000. Threshold of toxicological concern for chemical substances present in the diet: a practical tool for assessing the need for toxicity testing. Food Chem. Toxicol. 38, 255-312. https://doi.org/10.1016/s0278-6915(99)00120-9.

Kroes, R., Renwick, A.G., Cheeseman, M., Kleiner, J., Mangelsdorf, I., Piersma, A., Schilter, B., Schlatter, J., van Schothorst, F., Vos, J.G., Wurtzen, G., 2004. Structurebased thresholds of toxicological concern (TTC): guidance for application to substances present at low levels in the diet. Food Chem. Toxicol. 42, 65-83. https:// doi.org/10.1016/j.fct.2003.08.006.

Kusakabe, H., Yamakage, K., Wakuri, S., Sasaki, K., Nakagawa, Y., Watanabe, M., Hayashi, M., Sofuni, T., Ono, H., Tanaka, N., 2002. Relevance of chemical structure and cytotoxicity to the induction of chromosome aberrations based on the testing results of 98 high production volume industrial chemicals. Mutat. Res. Genet. Toxicol. Environ. Mutagen 517, 187-198. https://doi.org/10.1016/s1383-5718(02) 00062-1.

Lawrence, B.M., 2014. Progress in essential oils. Perfum. Flavor. 39, 68-75.

Lawrence, B.M., Tucker, A.O., 2002. The genus Thymus as a source of commercial products. In: Stahl-Biskup, E., Sáez, F. (Eds.), Thyme, the Genus Thymus. Taylor \& Francis, London, UK, pp. 252-262.

Llana-Ruiz-Cabello, M., Gutiérrez-Praena, D., Pichardo, S., Moreno, F.J., Bermúdez, J.M., Aucejo, S., Cameán, A.M., 2014a. Cytotoxicity and morphological effects induced by carvacrol and thymol on the human cell line Caco-2. Food Chem. Toxicol. 64, 281-290. https://doi.org/10.1016/j.fct.2013.12.005.

Llana-Ruiz-Cabello, M., Maisanaba, S., Puerto, M., Pichardo, S., Jos, A., Moyano, R., Camean, A.M., 2017. A subchronic 90 -day oral toxicity study of Origanum vulgare essential oil in rats. Food Chem. Toxicol. 101, 36-47. https://doi.org/10.1016/j. fct.2017.01.001.

Llana-Ruiz-Cabello, M., Maisanaba, S., Puerto, M., Prieto, A.I., Pichardo, S., Jos, A., Cameán, A.M., 2014b. Evaluation of the mutagenicity and genotoxic potential of carvacrol and thymol using the Ames Salmonella test and alkaline, Endo III- and FPGmodified comet assays with the human cell line Caco-2. Food Chem. Toxicol. 72, $122-128$.

Llana-Ruiz-Cabello, M., Maisanaba, S., Puerto, M., Prieto, A.I., Pichardo, S., Moyano, R., González-Pérez, J.A., Cameán, A.M., 2016. Genotoxicity evaluation of carvacrol in rats using a combined micronucleus and comet assay. Food Chem. Toxicol. 98, 240-250.

Llana-Ruiz-Cabello, M., Puerto, M., Maisanaba, S., Guzmán-Guillén, R., Pichardo, S. Cameán, A.M., 2018. Use of micronucleus and comet assay to evaluate evaluate the genotoxicity of oregano essential oil (Origanum vulgare l. Virens) in rats orally exposed for 90 days. J. Toxicol. Environ. Health 81, 525-533. https://doi.org/ $10.1080 / 15287394.2018 .1447522$.

Lucas, C.D., Putnam, J.M., Hallagan, J.B., 1999. 1995 Poundage and Technical Effects Update Survey. Flavor and Extract Manufacturers Association of the United States (FEMA), Washington, D.C.

Mahmoud, I., Alkofahi, A., Abdelaziz, A., 1992. Mutagenic and toxic activities of several spices and some Jordanian medicinal plants. Int. J. Pharmacogn. 30, 81-85.

Maisanaba, S., Prieto, A.I., Puerto, M., Gutiérrez-Praena, D., Demir, E., Marcos, R., Cameán, A.M., 2015a. In vitro genotoxicity testing of carvacrol and thymol using the micronucleus and mouse lymphoma assays. Mutat. Res. Genet. Toxicol. Environ. Mutagen 784-785, 37-44. https://doi.org/10.1016/j.mrgentox.2015.05.005.

Maisanaba, S., Prieto, A.I., Puerto, M., Gutiérrez-Praena, D., Demir, E., Marcos, R., Cameán, A.M., 2015b. In vitro genotoxicity testing of carvacrol and thymol using the micronucleus and mouse lymphoma assays. Mutat. Res. 784-785, 37-44. 
Marnett, L.J., Cohen, A.J., Fukushima, S., Gooderham, N.J., Hecht, S.S., Rietjens, I.M.C. M., Smith, R.L., Adams, T.B., Hallagan, J.B., Harman, C.L., McGowen, M.M. Taylor, S.V., 2013. GRAS flavouring substances 26. Food Technol. 67, 38.

Marnett, L.J., Cohen, S.M., Fukushima, S., Gooderham, N.J., Hecht, S.S., Rietjens, I.M.C. M., Smith, R.L., Adams, T.B., Bastaki, M., Harman, C.L., McGowen, M.M., Taylor, S. V., 2014. GRASr2 evaluation of aliphatic acyclic and alicyclic terpenoid tertiary alcohols and structurally related substances used as flavoring ingredients. J. Food Sci. 79, R428-R441. https://doi.org/10.1111/1750-3841.12407.

Maronpot, R.R., Flake, G., Huff, J., 2004. Relevance of animal carcinogenesis findings to human cancer predictions and prevention. Toxicol. Pathol. 32 (Suppl. 1), 40-48. https://doi.org/10.1080/01926230490425003.

Munro, I.C., Ford, R.A., Kennepohl, E., Sprenger, J.G., 1996. Correlation of structural class with No-Observed-Effect levels: a proposal for establishing a threshold of concern. Food Chem. Toxicol. 34, 829-867. https://doi.org/10.1016/s0278-6915 (96)00049-x.

Namiki, K., Yamanaka, M., Osawa, T., Namiki, M., 1984. Mutagen formation by nitritespice reactions. J. Agric. Food Chem. 32, 948-952. https://doi.org/10.1021/ jf00124a061.

Newberne, P., Smith, R.L., Doull, J., Goodman, J.I., Munro, I.C., Portoghese, P.S., Wagner, B.M., Weil, C.S., Woods, L.A., Adams, T.B., Lucas, C.D., Ford, R.A., 1999 The FEMA GRAS assessment of trans-anethole used as a flavouring substance. Food Chem. Toxicol. 37, 789-811. https://doi.org/10.1016/s0278-6915(99)00037-x.

OECD, 1997. Test No. 471: Bacterial Reverse Mutation Test. Organization for Economic Co-Operation and Development, Paris, France.

OECD, 2015. Guidance Document on Revisions to OECD Genetic Toxicology Test Guidelines. Organisation for Economic Cooperation and Development, Paris, France.

Pearse, G., 2006. Histopathology of the thymus. Toxicol. Pathol. 34, 515-547. https:// doi.org/10.1080/01926230600978458.

Proctor, D.M., Gatto, N.M., Hong, S.J., Allamneni, K.P., 2007. Mode-of-Action framework for evaluating the relevance of rodent forestomach tumors in cancer risk assessment. Toxicol. Sci. 98, 313-326. https://doi.org/10.1093/toxsci/kfm075.

Puskarova, A., Buckova, M., Krakova, L., Pangallo, D., Kozics, K., 2017. The antibacterial and antifungal activity of six essential oils and their cyto/genotoxicity to human HEL 12469 cells. Sci. Rep. 7 https://doi.org/10.1038/s41598-017-08673-9.

Reineccius, G., 1994. Natural flavoring materials. Source Book of Flavors. Springer, New York, NY, USA.

Rietjens, I.M.C.M., Cohen, S.M., Eisenbrand, G., Fukushima, S., Gooderham, N.J., Guengerich, F.P., Hecht, S.S., Rosol, T.J., Davidsen, J.M., Harman, C.L., Murray, I.J., Taylor, S.V., 2020. FEMA GRAS assessment of natural flavor complexes: Cinnamomum and Myroxylon-derived flavoring ingredients. Food Chem. Toxicol. 135 https://doi.org/10.1016/j.fct.2019.110949, 110949-110949.

Rojas-Armas, J., Arroyo-Acevedo, J., Ortiz-Sánchez, M., Palomino-Pacheco, M., CastroLuna, A., Ramos-Cevallos, N., Justil-Guerrero, H., Hilario-Vargas, J., HerreraCalderón, O., 2019. Acute and repeated 28-day oral dose toxicity studies of Thymus vulgaris L. Essential oil in rats. Toxicological Research 35, 225-232. https://doi.org/ 10.5487/TR.2019.35.3.225.

Roy, S., 2016. 4-Isopropyl-2-methoxy-1-methylbenzene (CAS\# 6379-73-3): in Vitro Mammalian Cell Micronucleus Assay in Human Peripheral Blood Lymphocytes (HPBL), Unpublished Study Report, Study No. AE21NN.348. BTL. BioReliance Corporation, Rockville, MD, pp. 1-52.

Roy, S., Jois, M., 2012a. Carvacrol: the in Vitro Mammalian Cell Micronucleus Test in Human Peripheral Blood Lymphocytes (HPBL), Study No. AD13HM.348. BTL. BioReliance, Rockville, MD.

Roy, S., Jois, M., 2012b. Thymol: the in Vitro Mammalian Cell Micronucleus Test in Human Peripheral Blood Lymphocytes (HPBL), Unpublished Study Report, Study No. AD13HL.348. BTL. BioReliance, Rockville, MD.

Rulis, A.M., 1989. Establishing a threshold of regulation. In: Bonin, J.J., Stevenson, D.E. (Eds.), Risk Assessment in Setting National Priorities. Springer US, Boston, MA, pp. 271-278.
Shoeibi, S., Rahimifard, N., Pirouz, B., Yalfani, R., Pakzad, S.R., Mirab Samiee, S., Pirali Hamadani, M., 2009. Mutagenicity of four natural flavors: clove, cinnamom, thyme and Zataria multiflora Boiss. Journal of Medicinal Plants 1, 89-96.

Sivaswamy, S.N., Balachandran, B., Balanehru, S., Sivaramakrishnan, V.M., 1991. Mutagenic activity of South Indian food items. Indian J. Exp. Biol. 29, 730-737.

Slamenova, D., Horvathova, E., Chalupa, I., Wsolova, L., Navarova, J., 2011. Ex vivo assessment of protective effects of carvacrol against DNA lesions induced in primary rat cells by visible light excited methylene blue (VL+MB). Neoplasma 58, 14-19.

Slamenova, D., Horvathova, E., Sramkova, M., Marsalkova, L., 2007. DNA-protective effects of two components of essential plant oils carvacrol and thymol on mammalian cells cultured in vitro. Neoplasma 54, 108-112.

Smith, R.L., Adams, T.B., Cohen, S.M., Doull, J., Feron, V.J., Goodman, J.I., Hall, R.L., Marnett, L.J., Portoghese, P.S., Waddell, W.J., Wagner, B.M., 2004. Safety evaluation of natural flavour complexes. Toxicol. Lett. 149, 197-207. https://doi.org/10.1016/ j.toxlet.2003.12.031.

Smith, R.L., Adams, T.B., Doull, J., Feron, V.J., Goodman, J.I., Marnett, L.J., Portoghese, P.S., Waddell, W.J., Wagner, B.M., Rogers, A.E., Caldwell, J., Sipes, I.G., 2002. Safety assessment of allylalkoxybenzene derivatives used as flavouring substances - methyl eugenol and estragole. Food Chem. Toxicol. 40, 851-870. https://doi.org/10.1016/s0278-6915(02)00012-1.

Smith, R.L., Cohen, S.M., Doull, J., Feron, V.J., Goodman, J.I., Marnett, L.J., Portoghese, P.S., Waddell, W.J., Wagner, B.M., Hall, R.L., Higley, N.A., LucasGavin, C., Adams, T.B., 2005. A procedure for the safety evaluation of natural flavor complexes used as ingredients in food: essential oils. Food Chem. Toxicol. 43, 345-363. https://doi.org/10.1016/j.fct.2004.11.007.

Smith, R.L., Cohen, S.M., Fukushima, S., Gooderham, N.J., Hecht, S.S., Guengerich, F.P., Rietjens, I.M.C.M., Bastaki, M., Harman, C.L., McGowen, M.M., Taylor, S.V., 2018. The safety evaluation of food flavouring substances: the role of metabolic studies. Toxicology Research 7, 618-646. https://doi.org/10.1039/c7tx00254h.

Stahl-Biskup, E., 2002. The genus Thymus as a source of commercial products. In: StahlBiskup, E., Sáez, F. (Eds.), Thyme, the Genus Thymus. Taylor \& Francis, London, UK, pp. 75-124.

Stammati, A., Bonsi, P., Zucco, F., Moezelaar, R., Alakomi, H.L., von Wright, A., 1999. Toxicity of selected plant volatiles in microbial and mammalian short-term assays. Food Chem. Toxicol. 37, 813-823. https://doi.org/10.1016/s0278-6915(99)000757.

Stofberg, J., Grundschober, F., 1987. Consumption ratio and food predominance of flavoring materials. Perfum. Flavor. 12, 27.

Surburg, H., Panten, J., 2006. Common Fragrance and Flavor Materials: Preparation, Properties and Uses. Wiley-VCH Verlag GmbH \& Co. KGaA, Weinheim, Germany.

Turkez, H., Aydin, E., 2013. Investigation of cytotoxic, genotoxic and oxidative properties of carvacrol in human blood cells. Toxicol. Ind. Health 32, 625-633. https://doi.org/10.1177/0748233713506771.

Ueno, S., Oyamada, N., Kubota, K., Ishizaki, M., 1984. The DNA-damaging activity of natural food additives (flavoring agents). J. Food Hyg. Soc. Jpn. 25, 214-218.

Undeger, U., Basaran, A., Degen, G.H., Basaran, N., 2009. Antioxidant activities of major thyme ingredients and lack of (oxidative) DNA damage in V79 Chinese hamster lung fibroblast cells at low levels of carvacrol and thymol. Food Chem. Toxicol. 47, 2037-2043.

Venskutonis, P.R., 2002. Harvesting and post-harvest handling in the genus Thymus. In: Stahl-Biskup, E., Sáez, F. (Eds.), Thyme, the Genus Thymus. Taylor \& Francis, London, UK, pp. 197-223.

Zani, F., Massimo, G., Benvenuti, S., Bianchi, A., Albasini, A., Melegari, M., Vampa, G., Bellotti, A., Mazza, P., 1991. Studies on the genotoxic properties of essential oils with Bacillus subtilis rec-assay and Salmonella/microsome reversion assay. Planta Med. 57, 237-241. https://doi.org/10.1055/s-2006-960081. 